\title{
GET IT RIGHT
}

How Home Office decision making fails refugees

A report from Amnesty International UK February 2004 
Get it Right: How Home Office decision making fails refugees A report from Amnesty International UK

February 2004

(c) Amnesty International United Kingdom

99-119 Rosebery Avenue

London EC1R 4RE

ISBN 1873328605

Product Code PB313

$£ 9.95$

By Jan Shaw and Rachel Witkin

\section{Acknowledgements}

Amnesty International UK is grateful to all who contributed to the information in this report, in particular:

Deri Hughes-Roberts and Shaji Revindran of the Refugee Legal Centre

David Rhys Jones of the Medical Foundation for the Care of Victims of Torture

Amanda Weston of Garden Court North Chambers

Dr Paul Williams of 'Arrival' NHS Practice in Stockton-on-Tees

Dr Michael Korzinski

Caroline Morten

Daniel Scheer

Philippe Bonavero 


\section{Contents}

1. Introduction

Terms and information

2. The obstacle course

The asylum application and initial decision making process

3. Getting it wrong

The need for objective and comprehensive country

of origin information

4. A negative culture

Unreasonable assertions about individual credibility

5. Talking of pain

Applicants who allege torture: The Home Office's consideration of credibility and medical evidence

6. Failing asylum seekers

Conclusions and recommendations

Endnotes

\section{Abbreviations}

AIT

APIs

CAT

CIPU

COI

ECHR

ELR

HEO

IAA

IAS

IAT
Asylum Immigration Tribunal

Asylum Policy Instructions

Convention against Torture

Country Information and Policy Unit

Country of origin information

European Convention on Human Rights

Exceptional Leave to Remain

Higher Executive Officer

Immigration Appellate Authority

Immigration Advisory Service

Immigration Appeals Tribunal
IDC Independent documentation centre

IND Immigration and Nationality Directorate

IPA Internal Protection Alternative

NASS National Asylum Support Service

NHS National Health Service

OGNs Operational Guidance Notes

PACE Police and Criminal Evidence Act

RFRL Reasons for Refusal Letter

SEF Statement of Evidence Form

SEO Senior Executive Officer

UNHCR UN High Commissioner for Refugees 


\section{1.}

\section{Introduction}

Asylum is one of the most contentious issues in the UK's political discourse. Often it is reduced to a simplistic numbers game, and the Government response has been to introduce more legislation, the cumulative effect of which is to undermine protection - a principle all major political parties in the UK purport to respect. Since 1997, the government has introduced three pieces of asylum-related legislation into Parliament designed to deter asylum applicants and make access to the UK's territory, asylum procedures and welfare benefits difficult for those fleeing human rights violations.

Amnesty International's report examines the quality of initial decision-making on asylum claims in the UK. This is of fundamental importance as the most recent legislation introduced in Parliament proposes to restrict appeal rights, replacing the current two-tier Immigration appeals system with a single tier of appeal and to abolish the powers of the higher courts to scrutinise decisions of the new appellate authority. The only possible challenge to a decision of the appellate authority would be for the authority itself to conduct an internal review. This will undermine protection for many asylum seekers who suffer from poor quality initial decisions and whose legitimate claims are at present subsequently upheld on appeal.

Asylum statistics produced by the Home Office show that in 2002, 22 per cent of rejected asylum applicants won their appeals against the refusal of asylum. This means that in nearly 14,000 cases the initial decision on the asylum claim was wrong - a serious indictment where such a mistake could be a matter of life and death for the individual. ${ }^{1}$

Statistics from July to September 2003 reveal that the Home Office continues to get the initial decision wrong as one in five refusals were overturned on appeal. When the appeal statistics are broken down by nationality, the number of appeals allowed due to poor Home Office decision-making looks stark:

585 Somalis (39 per cent), 65 Sudanese (36 per cent), 150 Eritreans (35 per cent), 465 Turkish (31 per cent), 95 Ethiopians (30 per cent), 320 Zimbabweans (29 per cent), 70 Cameroonians (29 per cent), 55 Congolese (28 per cent), 45 Colombians (28 per cent), 310 Iranians (27 per cent), 45 Burundians (27 per cent) and 35 Russians ( 26 per cent) had their initial decision by the Home Office overturned at appeal.

These figures show that the Home Office gets the decision wrong on many asylum claims from a wide variety of countries.

The House of Commons Home Affairs Committee shares Amnesty International's concern over Home Office decision making. In its report on Asylum Applications of 26 January 2004 the committee recommended:

We support the calls for greater 'front loading' of the applications system, that is, putting greater resources into achieving fair and sustainable decisions at an early stage. It is essential that better provision is made of good quality legal advice and interpretation services at the initial stage will not only serve the interests of justice, but eliminate much of the need for initial decisions to be reconsidered through the appeals process ....2

Amnesty International agrees with this recommendation. The quality of initial decision making on asylum claims has been a long-standing concern of the organisation. Getting more decisions right first time will lead to fewer appeals, thereby cutting the cost to the taxpayer. Fair initial decisions will raise public confidence in the asylum system and reduce the anxiety of asylum applicants.

It is the concern with poor quality initial decision making that has inspired this qualitative study based on the cases sent to Amnesty International by asylum applicants' solicitors asking for specialist information on countries of origin during 2003. In this period, the organisation received 175 asylum cases containing Home Office Reasons for Refusal letters. Extracts from Refusal letters cited in this report are taken from these cases, most of which are recent although a minority date back a few years. Throughout this study these extracts are referred to as 'Refusal letter extracts'. With the exception of those cases relating to minors, who were granted discretionary leave to remain until the age of 18 , none of the asylum applicants concerned had been given any form of protection in the UK at the time Amnesty International received their case. ${ }^{3}$

Refusal letters are issued by the Home Office to asylum applicants who are refused recognition as refugees under the 1951 United Nations Convention relating to the Status of Refugees (to which the UK is a signatory). They set out the reasons why an asylum applicant has been refused asylum under the terms of the Refugee Convention. An applicant who is refused asylum may be granted other forms of protection (see page 4). Since October 2000, Refusal letters have also included consideration of human rights issues under 
the European Convention for the Protection of Human Rights and Fundamental Freedoms (ECHR), which was incorporated into UK law by the Human Rights Act 1998. Amnesty International finds that the consideration of asylum claims with regard to both conventions is insufficient and inadequately explained in the majority of cases.

Most Refusal letters are two to four pages long. They consist of formulaic paragraphs, each containing reasons for refusal of the asylum claim. They are written only in English and they cite the 'opinion' of 'the Secretary of State', although they are in fact written by 'caseworkers' at the Immigration and Nationality Directorate (IND) of the Home Office. They use 'cut and paste' standard paragraphs which tend not to fit the specific case. These can be found on the Home Office IND website. ${ }^{4}$ They are contained in the Asylum Policy Instructions to caseworkers on the composition of RFRLs (Reasons for Refusal Letters). Refusal letters often contain grammatical and spelling errors which can make their content confusing. Their tone can be surprisingly cynical and dismissive, considering the often traumatic and sensitive details of the asylum claims concerned.

This study confirms Amnesty International's longstanding concern that the quality of initial decisionmaking on asylum claims in the UK is inadequate. It highlights three areas where standards of initial decision-making persistently fall short of those expected in a just and efficient asylum determination system:

1. Accurate information relating to the human rights situation in countries;

2. Objective consideration of issues relating to the individual credibility of asylum applicants;

3. Appropriate consideration of allegations of torture and medical evidence.

These three issues are examined in this report. But they do not represent all of Amnesty International's concerns with regard to initial decision making on asylum claims in the UK. The extracts from Refusal letters cited exemplify the approach of the Home Office to the various issues raised. They are not the only examples of inadequate Refusal letters received by Amnesty International.

For reasons of confidentiality, no names are given. The illustrative case studies used in this report are not intended to argue that specific individual asylum applicants should be granted Refugee Status, or are deserving of international protection. Their purpose is to isolate and examine the accuracy of Home Office knowledge and its fairness when considering asylum claims.

Amnesty International UK London, February 2004

\section{Terms and information about the UK's asylum processing system}

\section{Who is a 'refugee'?}

The Home Office is responsible for deciding whether an asylum applicant should be recognised as a refugee under the 1951 UN Convention relating to the Status of Refugees and granted refugee status. The purpose of the Convention is to ensure protection for people who have a 'well founded fear of persecution' because of their race, religion, nationality, political opinion or membership of a particular social group. These are complex legal terms and definitions, which are considered in the first instance by the Home Office.

\section{Other forms of protection}

Until April 2003 those who did not qualify for refugee status under the 1951 Refugee Convention but who were found to be in need of protection on human rights or other compassionate grounds, were granted Exceptional Leave to Remain (ELR). Under the Human Rights Act 1998, which came into force in October 2000, the Home Office considers a human rights claim at the same time as a refugee claim.

In April 2003 ELR was replaced by Humanitarian Protection $^{6}$ which is granted to anyone who would, if removed, face in the country of return a serious risk to life or person arising from:

the death penalty

unlawful killing

torture or inhuman or degrading treatment or punishment.

A further category, Discretionary Leave to Remain, was created for the Home Secretary to retain the ability to allow some of those who fall outside the Humanitarian Protection Policy to stay on a discretionary basis.

Discretionary Leave to Remain will only be considered by caseworkers once a decision has been made on whether the applicant qualifies for asylum or Humanitarian Protection. Unlike Humanitarian Protection, Discretionary Leave to Remain is granted outside the Immigration Rules. 


\section{2. \\ The obstacle course}

\section{The asylum application and initial decision-making process}

The complexity of asylum cases is acknowledged in the United Nations High Commissioner for Refugees (UNHCR) Handbook on Procedures and Criteria for Determining Refugee Status, which is the guide that all professionals who use the $1951 \mathrm{UN}$ Refugee Convention, including Home Office caseworkers ${ }^{1}$, are expected to use.

Asylum claims are a unique area of law. Because the circumstances of departure from a country often relate to a complex accumulation of events, they can involve the recounting of the entire lives of people who are vulnerable - and made more so by their lack of status during the determination process.

The burden of proving their case is on the asylum applicant, but the very circumstances of the case will probably make this very difficult. Therefore, it is only fair for the examiner (who is often the decisionmaker) to share the duty of ascertaining and evaluating all the relevant facts, and for the examiner to help the applicant as far as possible present their case for consideration. ${ }^{2}$

\section{Explaining the asylum case}

On arrival, asylum seekers may be suffering from illness or injury resulting from events or conditions in their own country, or their hazardous journey to the UK. Some will be suffering psychological distress after the death, torture or 'disappearance' of family members. ${ }^{3}$

Asylum seekers are required to explain why they are seeking protection in the UK. This means recounting personal details about themselves and their family and the circumstances which caused them to flee their country. It can often involve remembering extremely traumatic, humiliating and distressing events which they have to communicate quickly, often through an interpreter, to a solicitor with whom they have not had the time to develop a trusting relationship.

Many asylum seekers come from countries where people who are in authority or an 'official' position are perceived as a threat to their personal safety. It is therefore very difficult for them immediately to trust a solicitor, or anyone who appears to be an authority figure, with the intimate details of their life. Some may be afraid to speak in front of interpreters from their own country; others may have a history of torture or sexual abuse that they feel ashamed about or unable to discuss for cultural or psychological reasons. ${ }^{4}$

Those from countries with very strict regimes will often find it particularly difficult to disclose full details of their political opinion or sexual orientation at the first stage of giving instructions to the solicitor. For many asylum seekers the whole process is confusing and alien to procedures they are familiar with in their own country. It is difficult for them to know what is required of them.

Since 8 January 2003, some asylum seekers are not entitled to benefits in the $\mathrm{UK}^{5}$ and have the immediate worries of how to obtain food and accommodation at the same time that they are endeavouring to give an accurate account of their claim.

Most asylum applicants are required fill in a Statement of Evidence Form (SEF) to set out the claim for asylum. This 19-page form must be completed in English and submitted to the Home Office within 10 working days of the date of the asylum claim. The application is refused on noncompliance grounds if, for example, the form does not arrive within the specified time. According to Home Office statistics this currently occurs in around 15 per cent of cases. For many of these rejected asylum applicants, the first time their case is heard on its merits will be at the appeal hearing. This is an inefficient use of public resources.

An SEF is issued by immigration officers where applications are made at the port or by the Asylum Screening Unit at the Home Office. SEFs are not used in Dover where there is a Home Office pilot project. Dover is an Induction Centre ${ }^{6}$ but many of the asylum applicants dealt with there will not have arrived at Dover. It appears that the Home Office is moving towards a process where all asylum seekers will go through an Induction Centre or fast track procedure.

\section{Access to legal advice and representation}

Amnesty International has recommended that the initial decision making on asylum claims should be 'front-loaded' which means that resources should be focused on good quality defensible decisions early in the decision-making process. 'Front-loading' enhances efficiency by ensuring that the initial Home Office decision is based on a full understanding of 
the applicant's case and is therefore reliable.

An essential component of such an approach is that asylum seekers should have access to early provision of good quality legal advice so that the individual can make a full statement of all the relevant elements of their claim for refugee status. Early access to legal advice also enhances the quality of the initial decision, and so avoids wasting public funds on appeals against ill-founded refusals.

Finding good quality legal representation is problematic. There is unequal provision of good quality legal representation around the UK and with the proposal to restrict publicly funded immigration and asylum work, many established solicitors might have to withdraw from this area of work. ${ }^{7}$

Many asylum seekers do not speak English as a first language and the Home Office's own commissioned research demonstrates that they are unlikely to be knowledgeable about UK asylum procedures or legal system. ${ }^{8}$ Nonetheless, they will need to obtain the services of a solicitor within a very short time to submit their SEF by the 10-day deadline for those not in fast-track procedures.

\section{Home Office interviews}

At some point before the initial decision is made on their case, the majority of asylum seekers will be substantively interviewed about their claim. Interviews are conducted by Home Office asylum caseworkers and generally occur after the initial SEF application has been submitted. The interview is central to an asylum claim and forms a substantial part of the evidence on which initial decisions are based. During the interview asylum applicants are asked about their background, their reason for claiming asylum in the UK and the risk they may face on return to their country. The interview concerns matters which relate to the life and liberty of applicants. It is essential that the interview should present a real opportunity for an applicant to speak freely about his or her claim for protection in the UK.

During the asylum interview, a hand-written record of the questions asked and the applicant's responses is taken. For applicants who do not speak English, questions will be asked through an interpreter, and the responses relayed back through the interpreter to the interviewer. At the end of the interview, the applicant is asked to sign the official hand-written record of what has been said. Only in exceptional circumstances will this be read back to the applicant in his or her native language and this practice has largely been abandoned. ${ }^{9}$ Therefore the vast majority of asylum applicants are expected to sign an interview record in a language they do not understand, without having the opportunity to read it. This differs from the treatment of testimony in any other area of the UK legal system.
Many problems can occur at asylum interviews. Because they are often conducted through an interpreter, misunderstandings and misinterpretations can arise. Applicants may suffer anxiety about revealing their background in front of a third party who is from their own country or who is of the inappropriate gender for the content of the specific asylum claim. ${ }^{10}$

Many Home Office caseworkers appear to lack basic interviewing techniques which would put the applicant at ease. Without adequate knowledge of the human rights situation in the country of origin, caseworkers may follow a line of questioning that is not conducive to establishing the full content of the asylum claim.

Therefore it is essential that a legal representative and independent interpreter are present at asylum interviews. The legal representative can take their own hand-written record of the interview to ensure a full, accurate account of everything that is said and note any issues of procedure or miscommunication that arise. The independent interpreter can also take a record of the interview in the first language of the applicant, ensuring that any mistakes in interpretation are noted. The representative and interpreter can make comments at the end, raising any issues of procedure or interpretation before the interview has ended.

At present, good quality representatives ensure that asylum applicants are represented in this way. However, many applicants do not have the benefit of representation and few will have such access in future owing to changes to publicly funded immigration and asylum work which come into force from April 2004. In future asylum applicants will be represented at interviews only in exceptional circumstances. ${ }^{11}$ Amnesty International is concerned that this will further degrade the accuracy of Home Office initial decision making and strongly supports the right of applicants to be represented at interview.

\section{Training, monitoring and assessment of caseworkers}

Amnesty International supports the recommendation by the House of Commons Home Affairs Committee on Asylum Applications (26 January 2004) that the overall calibre and training of caseworkers who take initial decisions on asylum applications should be reviewed. ${ }^{12}$ This organisation believes that the Home Office should initiate longterm and continuing training, including external training, of caseworkers in international refugee and human rights law, and specialist country knowledge and expertise.

Currently all new asylum caseworkers attend an initial 11-day training course followed by a further 13 days in a Mentoring Unit where their casework skills are developed first through 'dummy' and then 
through 'live' cases. In addition, there is a three-day intensive interviewing course. Experienced caseworkers continue to receive training as and when required. ${ }^{13}$ The Home Office has told Amnesty International that caseworkers attend a 'consolidating workshop' after three months. Caseworkers who deal with non-suspensive appeal cases (where the applicant must leave the UK before appealing) receive additional training. ${ }^{14}$

UNHCR has been conducting training for Home Office asylum caseworkers in Liverpool for the past two years. In November 2003, a similar training programme was initiated for caseworkers based in Croydon. Each three-to-four-hour training session focuses on the global protection concerns of refugees, the role of UNHCR and the role which credibility plays in the refugee status determination process.

Random samplings of decisions on asylum cases are carried out by internal and external assessors. Each caseworker is expected to make at least one decision a day and is assessed internally by a senior caseworker on one of their initial decisions each month, on a case picked at random. According to the Home Office, decisions can be remedied at this stage before they are communicated. External sampling of cases is provided by the Treasury Solicitors. ${ }^{15}$

The Home Office will publish performance data in due course but claims that both internal and external assessments indicate that the target of 80 per cent of decisions assessed as fully effective or better is being met and that quality is improving. ${ }^{16}$

Amnesty International believes that random sampling of cases is not an adequate monitoring system to ensure the quality of initial decision making in asylum applications.

The quality of initial decision making in asylum cases was raised during the second reading of the Asylum and Immigration Bill in the House of Commons on 17 December 2003. The Home Secretary, David Blunkett, acknowledged that further steps had to be taken to improve decision making.

UNHCR has embarked on preliminary discussions with the Home Office to determine how it might help the Home Office to improve the quality of its decision making.

\section{The time taken for initial decision making}

When the government came to power, the Home Office was taking an average of two years to process initial decisions on asylum claims in substantive cases. It now reaches its target of processing 75 per cent of new asylum claims within eight weeks. Amnesty International acknowledges that quicker decisions can reduce the uncertainty and psychological suffering of applicants. However, this only applies if processing and initial decision making are reliable. Speeding up the decision-making process is beneficial only if it is not at the expense of quality.

Asylum claims which appear to be 'straightforward' are put through 'fast-track' procedures, for example at Harmondsworth Immigration Removal Centre or at Oakington Reception Centre. At Harmondsworth, the Home Office aims to make an initial decision within three days. Once the application is decided and most likely refused, the applicant continues to be detained during the appeal process pending removal from the UK. At Harmondsworth, all decisions are made at Higher Executive Officer level rather than at the lower grade. ${ }^{17}$ The entire process, including appeals to the Immigration Appellate Authority, is supposed to take just 22 days from start to finish. ${ }^{18}$

The re-emergence of a list of safe countries (the White List) - currently 24 countries - from which asylum claims will be presumed to be unfounded means that significant numbers of applicants no longer have any 'in-country' right to appeal against refusal of their claim ('non-suspensive appeal cases'). ${ }^{19}$ These applicants are among those held at Oakington Reception Centre. The decision letters in such claims are approved by a senior caseworker at Higher Executive Officer (HEO) or Senior Executive Officer (SEO) grade before the decision is served.

At Oakington, applicants with no right to appeal while they remain in the UK have an expected departure date set for seven days after arrival, but in many cases this target is not reached. According to the latest statistical data available from the Home Office, 100 per cent of the asylum seekers detained at Oakington who received decisions on their claim were refused.

A number of cases are deemed inappropriate for the Oakington process, for example where an asylum seeker is given an appointment with the Medical Foundation for the Care of Victims of Torture. In such cases, the applicant is released and given temporary admission while their application is processed.

The Fast Track Suitability list currently comprises 66 countries including the 24 countries on the 'White List'. ${ }^{20}$ 
3.

Getting it wrong

\section{The need for objective and comprehensive country of origin information}

Detailed, accurate and up-to-date information about the country of origin of an asylum applicant is essential to make an informed decision on an asylum claim. It is also very important that the decisionmaker has an understanding of the cultural context and implications of situations for asylum applicants from specific countries.

At present, the responsibility of providing the country assessments rests with the Home Office's 'Country Information and Policy Unit' (CIPU). The Home Office advises its caseworkers to make decisions on asylum claims based on its own country information. CIPU currently publishes Country Assessments on 35 refugee-producing countries each year, in April and October. These are intended to provide impartial information on countries. At the beginning of each Country Assessment ${ }^{1}$ it states:

The document does not contain any Home Office opinion or policy.

However, CIPU Country Assessments have been widely criticised for their selective use of information, including listing quotes and events without any meaningful analysis or context, and often giving an inaccurately positive picture of human rights situations in countries where serious violations are taking place. At no point in Country Assessments is there an acknowledgement that obtaining accurate information about human rights situations in 'closed' countries is difficult or any different from obtaining information about countries which are more 'open' to monitoring.

The Immigration Advisory Service (IAS), which recently carried out a study of Country Assessments, says that they 'often take information supplied by the governmental bodies of the countries and legislation at face value, and do not go on to assess whether that which is supposed to occur is actually occurring' (emphasis AI). ${ }^{2}$ The acceptance by the Home Office of such information indicates that the Country Assessments contain implicit 'opinion and policy' - based on an assumption that the majority of asylum claims have no factual basis.

This problem is compounded by the selective use of referenced material. Aside from Country Assessment sources being wrongly cited, or out of date, quotations are often summarised or shortened, giving a more positive outlook about the human rights situation in a country than is stated in the source material.

A second statement at the beginning of each Country Assessment reads:

The report has been prepared for background purposes for those involved in the asylum/human rights

determination process. The information it contains is not exhaustive. It concentrates on the issues most

commonly raised in asylum/human rights claims made in the United Kingdom. (emphasis Al)

Despite the acknowledgement that the information contained in the Country Assessment is 'not exhaustive', a senior caseworker at the IND who was recently interviewed by Amnesty International for this report told the organisation that caseworkers were discouraged from searching for alternative sources on the Internet. They were instructed to contact CIPU through a senior caseworker if further information was required about a claim. This casts considerable doubt on the third statement on each Country Assessment:

[The report] is intended to be used by caseworkers as a signpost to the source material, which has been made available to them. The vast majority of the source material is readily available in the public domain.

In reality, sources which are referenced (not all are) in the Country Assessments are often very difficult to follow up. The accessibility of sources varies and can often lead to further secondarily sourced quotations, rather than to primary material. A research study commissioned by the Home Office in $2001^{3}$ was critical of what it referred to as the reliance on the 'round-tripping' of secondary information and the lack of primary 'fact-finding' by CIPU. The regurgitation of secondary information in Country Assessments obviously leads to inaccuracy and information that quickly becomes out of date. It does not allow for necessary 'cross-checking' and verification of information prior to its release, but instead accepts the veracity of repeated facts without validating them.

Caseworkers also have access to CIPU 'Bulletins' which update country information in between assessments and Operational Guidance Notes (OGNs) which are policy driven and will therefore not be reviewed by the CIPU Advisory Panel. This lack of review is unfortunate, considering that the 
quality of OGNs has also been criticised. ${ }^{4}$

The Home Office research study also criticised the lack of a methodology for primary fact-finding missions undertaken by the Home Office. At present, Country Assessment reports have been produced from fact-finding missions to Eritrea, Iraq, Rwanda and Sri Lanka. Amnesty International, which conducts fact-finding missions itself where possible for the basis of its research, believes that fact-finding missions are preferable to secondary sourcing of information. However Home Office fact-finding missions have been criticised for 'lack[ing] any coherent methodology and relying heavily on government sources'.

Amnesty International found that the Eritrean fact-finding mission was well-researched and gave due weight to human rights concerns. However, the resulting confidential report, which was provided to Amnesty International, did not adequately describe the limitations on who the members of the mission were able to meet in Eritrea. It failed to explain the omission of interviews with independent Eritreans (rather than officials). Given the current extreme political repression in Eritrea, it is very difficult for official visiting delegations to meet independent Eritrean citizens, owing to the extensive security surveillance. They would be at risk of reprisals on suspicion of criticising the government, or even supposed espionage or treason. This information is significant in illustrating the 'closed' nature of the situation in Eritrea at the current time.

Amnesty International believes that CIPU reports are not sufficient for determining asylum claims. In addition, it is not clear from the IND website where caseworkers can obtain information about countries in which the human rights situation is complex, but for which there are no CIPU Assessments, OGNs or Bulletins. According to the Home Office, such countries are covered by information held in country bundles by senior caseworkers. These bundles are sourced by CIPU but are not accessible to the public. If caseworkers require further information, they can ask their senior caseworker to contact CIPU on their behalf.

Amnesty International believes that as the purpose of Country Assessments and related CIPU reports is to provide context for examination of asylum claims, it would be better for caseworkers to have access to reports which fully document the real risks faced by different asylum applicants on enforced return. Country Assessments and other CIPU reports should clarify likely human rights abuses as well as the realistic humanitarian situation with regard to both individual and family returns. The assessments should also encourage independent reference to reputable country experts.

As most Country Assessments are currently set out, the risk faced by different asylum seekers on enforced return to a country can be deduced only indirectly. Home Office caseworkers acknowledge that this can present problems for accurate decision making. In a recent research study commissioned by the Home Office, it was found that some Home Office caseworkers felt the need for more detailed information on political parties, political circumstances, detention in the country of origin, the use and methods of torture, the role of the judiciary and the police, socio-economic conditions, medical facilities and gender-related issues including sexual orientation. ${ }^{6}$

Many asylum and country experts have criticised the Home Office's reliance on CIPU information throughout the asylum process - not least because it is produced by the party making the initial decision on the case. This undermines the claim that the information is 'impartial'. The 'dual role' of the Country Information and Policy Unit, apparent in its very title, has also been criticised. The same individuals who are responsible for researching information on particular countries for CIPU reports also provide policy advice to Ministers about asylum applications from that country. Amnesty International believes that the roles of 'Country Information' and 'Policy' are in conflict and should not sit together.

Asylum specialists and human rights organisations, including Amnesty International, have repeatedly requested an Independent Documentation Centre which could provide impartial information on countries, and therefore be relied upon by both sides. This would mean that information could be produced by recognised country experts, properly trained in country research and the management and analysis of information - and free of concerns related to asylum targets and government policy.

Under the Nationality, Immigration and Asylum Act 2002, an Advisory Panel on Country Information was set up to 'to consider and make recommendations to the Secretary of State about the content of country information' produced by the Home Office. The Panel will meet twice annually to review and advise on the content of country information and on the methods of research and quality control of CIPU. It is made up of senior specialists in various related fields, but the Panel itself is concerned that it lacks country experts capable of reviewing the factual content of CIPU material. ${ }^{8}$ At its first meeting in September 2002, the Panel noted the absence of any human rights organisations and legal representatives as 'constituting a gap' in its membership.

Concern has been expressed by those working on behalf of asylum applicants, as to how, or even if, some Home Office caseworkers use the Country Assessments. The Home Office's own research has 
revealed a lack of training of caseworkers in using CIPU country information. Some caseworkers felt they were already sufficiently informed about specific countries and had no need to refer to it:

We build up our knowledge because I work on top asylum producing countries - Sri Lanka, Iran - so you don't need to look at it after a while.... I have been here longer than most so I don't tend to use country information. The information they [the Assessments] provide is so familiar, we don't necessarily use any CIPU information. ${ }^{9}$

This statement is worrying, especially considering the complexity of human rights situations and events in the two countries mentioned, Sri Lanka and Iran.

Another concern raised in the Home Office research study was that caseworkers had too little time to consider Country Assessments properly at each stage of the decision-making process. This is not surprising, considering the targets set by the Home Office for asylum case processing, and its focus on the number of decisions reached, rather than the quality of decision making.

\section{Lack of information about political parties}

Home Office Refusal letters are not based on adequate information about political parties, or about the consequences of enforced return of asylum applicants who are members or supporters of specific political parties. Because caseworkers have access only to CIPU information, if the substance of a claim falls outside the country information available, it will not be considered sufficiently. This is supported by research commissioned by the Home Office itself, in which a caseworker stated:

We need to know whether particular groups or political parties exist, but instead we are told to say that the Secretary of State is not aware of this group so therefore it is unlikely to be of interest to the authorities. But really they have no information on whether the group existed. ${ }^{10}$

\section{Syrian Kurd}

\section{Refusal letter extract, February 2001}

The basis of your claim is that you fear persecution in Syria because of your political beliefs. You are a member of the Hergirtin. - The Secretary of State is not aware that this party actually exists.

\section{Amnesty International comment} According to Al information, the 'Hergirtin' Party ('Hevgirtina Gel a Kurd li Sûriya' or 'Hevgirtina Gel') exists in Syria. The party is unauthorised by the Syrian state and therefore operates in secret. In Syria, Kurdish parties are perceived as 'separatist', and involvement with such organisations at any level is a serious crime which can lead to imprisonment and torture under Article 267(1) and (2) of the Syrian Penal Code.

The consequences of return to Syria for this applicant would have been extremely serious, and yet it is likely that this refusal was based on nothing more than a paucity of information in CIPU. After Amnesty International submitted information on this case, the Adjudicator at the Immigration Appellate Authority found that:

It is clear from the letter from Amnesty International that the party does exist and I also had before me a letter on headed notepaper from the party. - I am therefore prepared to accept that it does indeed exist.

- Hevgirtina Gel a Kurd li Sûriya was formerly under the umbrella of the Yeketi Party but now operates independently. The party was founded in 1975, and was then named Partya Dêmokratî Kurd a Cep li Sûriya. It has been known as 'Hevgirtina Gel' since 1980.

\section{Asserting the official position of governments on human rights violations}

Where human rights violations have been committed by the authorities, Refusal letters tend to assert that the same authorities do not condone such practices and are taking, or have taken, steps to put a protection system in place. The Asylum Policy Instructions on Reasons for Refusal letters provide standard paragraphs to help caseworkers to refute claims on this basis. The following paragraph demonstrates a 'fill-the-gaps' approach to individual applicants from many different countries and of varied circumstances:

You stated that the [police/name of other body] [describe alleged actions]. The Secretary of State considers that these are the random actions of a few rogue [police officers/soldiers/individuals] abusing their official position. The Secretary of State is of the opinion that such actions are not knowingly tolerated by the authorities of [COUNTRY] and that the authorities are able and willing to provide effective protection [CITE CIPU REPORT]. You made no attempt to report these incidents to [name body should have reported to/authorities]. The Secretary of State is of the opinion that you could have attempted to seek redress through the proper authorities before seeking international protection. (emphasis Al)

$$
\text { AND }
$$

In order to bring yourself within the scope of the Convention, you would have to show that these incidents were not simply the random actions of individuals but were a sustained pattern or campaign of persecution directed at you which was knowingly tolerated by the authorities, or that the authorities 
were unable, or unwilling, to offer you effective protection. ${ }^{11}$

The accompanying advice about how to use standard paragraphs of this nature indicates how the Home Office believe CIPU reports should be used and referred to:

NOTE: caseworkers should cite the particular paragraphs in the relevant CIPU report which leads them to believe that the police are not complicit and that prosecution is actively pursued. ${ }^{12}$ (emphasis Al)

\section{Algeria}

\section{Refusal letter extract, March 2003}

You claim that as soon as you arrived at the Central Police Station you were tortured. You claim that while you were handcuffed one of the men asked you questions and started to hit you in the face and that you were cursed. You claim that during this time they wanted you to admit that you had killed your friend but you refused. You claim that you were kept in a prison cell and that they brought you back again to the same office for more questioning. You claim that they placed soapy rags in your mouth until you agreed to sign the paper because you were very ill and you were not aware of your actions. You also claim that one night two of the guards, came into the prison cell and raped you.

\section{Amnesty International comment}

This description is consistent with reports of torture in Algeria received by Amnesty International in recent years. Since the early 1990s, the organisation has spoken to or received testimonies from scores of torture victims and family members of victims who have described similar experiences. Many victims describe having 'soapy rags', or chiffons, stuffed inside their mouths. They are then often forced to swallow large quantities of dirty water, urine or chemicals through the rags. There has been a relative increase in the use of this method in the past two or three years because it leaves few traces.

However, rather than considering this matter in the context of accurate country information, the Home Office issued a denial based on the stated position of the Algerian government:

\section{Algeria continued}

\section{Refusal letter extract, March 2003}

You claim that you were ill-treated during detention, tortured and raped. The Secretary of State does not condone any violations of human rights which may have been committed by members of the security forces in Algeria. However, he does not accept that they are evidence of persecution within the terms of the United Nations Convention.
The Secretary of State further notes that the Algerian Government does not condone such violations. The Algerian government's stated position and instances where members of the security forces have been arrested for such violations is set out in US State Department Human Rights Reports and the current Home Office Country Assessment.

In order to bring yourself within the scope of the United Nations Convention, you would have to show that these incidents were not simply the random acts of individuals but were a sustained pattern or campaign of persecution directed at you which was knowingly tolerated by the authorities or that the authorities were unable or unwilling to offer you effective protection. (emphasis Al)

\section{Amnesty International comment}

Amnesty International's research indicates that torture in Algeria remains prevalent and systematic in nearly all cases involving alleged links to what the government describes as 'acts of terrorism or subversion'. However, torture is not confined to cases of this kind. The security forces have also repeatedly tortured political activists arrested during or after demonstrations protesting against government policies or measures. Amnesty International does not accept the Algerian government's refusal to acknowledge that secret detention and torture are a problem in Algeria.

Thus an application from Algeria can be refused on the basis of the Algerian government's statements. Amnesty International finds this approach to Algerian asylum claims very worrying, especially considering the indication in the Home Office's own research that it may be widely applied:

If I'm dealing with a difficult country I may have to grant status but run of the mill countries, I know what to expect. I know that they are likely to be economic migrants so I'll refuse. For an Algerian case, I'll read the Country Assessment and OGN and then I'll decide to refuse. I'll check to see if there are any standard paragraphs and insert these together with anything else on credibility and general paragraphs on country information. I use an OGN and the country assessments when I start to work on a country, on a new country. After a few cases, I don't tend to refer to them anymore and I just use the standard paragraphs. ${ }^{13}$ (Home Office caseworker)

This approach is also seen in relation to Iran, a country where torture and human rights violations are of extreme concern to Amnesty International. 


\section{Iran}

Refusal letter extract, March 2003

The Secretary of State does not condone any violations of human rights which may have been committed by members of the security forces in Iran. However, he considers that these actions arise from failures of discipline and supervision rather than from any concerted policy on the part of the Iranian authorities and does not accept that they are evidence of persecution within the terms of the United Nations Convention.

\section{Amnesty International comment}

The nature of the separation of powers in Iran means that it is inaccurate to refer to 'concerted policy' of 'the authorities', without specifying which branch of the 'authorities' are meant. Amnesty International continues to receive reports of flagrant human rights violations, including torture, which are alleged to have been carried out by authorities who are not under the legal or informal control of the government, including those allegedly carried out by unofficial bodies such as the Ansar-e Hezbollah (Partisans of the Party of God) or the Basiji forces.

No authority in Iran would officially 'condone' torture. However, it is notable that in December 2003, the Council of Guardians (the highest legislative body which screens all laws in Iran to ensure that they are in keeping with the Constitution and Islamic tenets) refused to sign the UN Convention Against Torture (CAT) on financial and religious grounds. Torture in Iran is constitutionally prohibited only if it is for the purpose of extracting confession. Torture in Iran remains of concern to Amnesty International, notably in the context of incommunicado and pre-trial detention, where it is used to frighten and intimidate political activists.

The Iranian government's executive branch, which has called for and conducted its own investigations into allegations of human rights violations, has no legal or constitutional authority over organisations which enforce or protect 'national security' against perceived internal or external threats. The Supreme Leader appoints the heads of, among others, the Revolutionary Guard, the Law Enforcement Forces (LEF or Nirou-ye Entezami-e Iran) and the judiciary, which are the principle organs responsible for alleged breaches of 'national security' and/or public order.

\section{Lack of information about the significance of political activism in specific countries}

\section{Iran}

\section{Refusal letter extract, April 2003}

You claimed to fear persecution in Iran because of your political beliefs, yet, the Secretary of State notes that you were not a member of an organisation. He finds it rather implausible that the authorities would take an interest in someone who is only a low-level activist and not a member of a particular party.

\section{Amnesty International comment}

In Iran, there is no legally defined difference between 'high-' and 'low-' level political activists. A person who is not a member of a political organisation but is perceived to have taken part, at any level, in activities that express opposition to the State, may face arbitrary arrest, incommunicado detention and torture in Iran, owing to the widespread enforcement of vaguely worded laws relating to national security

Amnesty International believes that political activists who are 'low-level' in the sense of having no national or international profile, may be at an increased risk of torture or ill-treatment in detention, because the details of their treatment are less likely to become publicly known.

\section{Lack of knowledge about sexual orientation and related legislation in countries of origin}

The Home Office also presents an optimistic picture of the situation for homosexuals in various countries. One country that Amnesty International has campaigned on with regard to the rights of homosexuals is Egypt.

\section{Egypt}

Refusal letter extract, January 2003 You claim to be at risk of persecution by the Egyptian authorities because you are a homosexual. The Secretary of State understands that Islam prohibits homosexuality, although it is not explicitly referred to in the Egyptian penal code. There exist a wide range of laws covering obscenity, prostitution and public decency, and the Secretary of State is aware that homosexuals have difficulty in openly stating their sexuality in Egypt.

You have alleged that you have been arrested and detained by the Egyptian police on account of your sexuality. The Secretary of State has noted that although you claim to have been charged by the 
police, the offence of homosexuality is not a recognised offence in Egypt.

\section{Amnesty International comment} Article 9(c) of Law 10 of 1961 on Combating Prostitution in Egypt stipulates police sentences of between three months and three years for those who 'habitually practise debauchery' or prostitution. Article 15 allows for police supervision to be imposed, for a period up to the equivalent of the prison sentence, on release from detention. Although there is no explicit reference to homosexuality in Egyptian legislation, the term 'debauchery' is applied to same sex relations in the context of prostitution of men, as well as to consensual sexual relations between men in private. Amnesty International has investigated numerous cases of this kind.

The written verdict of the Emergency Supreme State Security Court for Misdemeanours, 14 November 2001, of 52 allegedly gay men does not confine itself to the term 'debauchery' and makes numerous references to 'sexual deviancy' (Arabic: 'Shudhudh') - a perjorative word for homosexuality. 'Habitual debauchery' as defined in the verdict can amount to merely practising consensual sexual relations between men.

\section{Egypt continued}

\section{Refusal letter extract, January 2003}

Further doubts on the veracity of your claim can also be drawn from the fact that you did not seek legal advice following your release. Considering that you claim to have been charged by the police, the Secretary of State is aware of the publicity surrounding the raid and arrest by police of more than fifty men in early May 2001 on the Queen Boat, a tourist boat moored on the Nile and known as a venue for homosexuals. The ensuing trial received much international publicity and resulted in the conviction of $\mathbf{2 3}$ men for morality offences, whilst a further 29 were acquitted. The incident is seen as indicative of the authorities' intolerance of homosexuality in Egyptian society and there continue to be appeals from abroad for clemency for the remaining men in custody. Notwithstanding the fact that the Secretary of State does not accept that you have been arrested and charged by the police, he believes it reasonable that you would have been able to see a lawyer regarding your situation. The fact that the men arrested in the Queen Boat raid were tried and in some cases continue to appeal, confirms that legal advice is available and your failure to consult a lawyer damages the veracity of your claim.

\section{Amnesty International comment} With few exceptions, even human rights organisations in Egypt have refused to support people who are targeted for their sexual orientation. Amnesty International is aware that alleged homosexuals are reluctant to report torture or ill treatment - in particular after their release from detention - fearing that a complaint would lead to further harassment.

Homosexuals in Egypt suffer discrimination, persecution and violence, simply for being who they are. Those who are detained because of their actual or perceived sexual orientation are deemed to threaten socially accepted norms and are at particular risk of torture and illtreatment, and other human rights violations.

\section{Inaccurate information on the sufficiency of protection in countries of origin}

Jamaica is currently one of the 24 allegedly 'safe countries' (White list) from which asylum claims are presumed to be unfounded and Jamaican nationals therefore do not have the right to remain in the UK to appeal against a refusal of their claim. Despite this, the Home Office's information on Jamaica presents a falsely optimistic picture.

\section{Jamaica}

\section{Refusal letter extract, April 2003}

In the light of ongoing initiatives by the Jamaican Government to fight crime and gang violence with the co-operation of both the police (JCF) and the military (JDF), there is a general sufficiency of protection for victims of criminal violence in Jamaica. New policing initiatives and approaches to crime control appear to have reduced fighting and tension in some of the inner city areas of Kingston. In Tavares Gardens, in the St. Andrew South Division, nearly 100 days after the Government imposed a 24-hour curfew on the neighbourhood fighting has all but stopped. The National Security Minister has attributed this success to the police maintaining a longer presence in these areas and developing a community style of policing. In a major public relations campaign, the Jamaican military and police are not only keeping order but tiling school classrooms, demolishing derelict buildings and clearing garbage. The intelligence capacity of the police force has greatly increased and the personnel focussing on organised crime, gangs and other groups are now preparing a list of names as well as arrest and search warrants. The Secretary of State considers that this demonstrates the willingness by the Jamaican authorities to deal with the problem of political/garrison violence.

The Secretary of State is aware that the Jamaican public views the Police as not committed to their responsibility for providing protection from criminals and there are suspicions that a minority of officers may actually be involved in criminal activity. To address these perceptions the Secretary of State is aware that the Jamaican government has created two units within the 
JCF responsible for investigating alleged abuse or misconduct by the police.

\section{Amnesty International comment}

There is no 'general sufficiency of protection for victims of criminal violence' in Jamaica. While it is true there have been a number of initiatives by the Government in recent times, these have, to date, failed to stem the high levels of violent crime faced by numerous communities. This is evidenced by the continuing high murder rate. There were 975 murders reported in 2003 , one of the highest pro rata rates in the world. Seven people were killed in Kingston on a single day on 28 December 2003. In Spanish Town two rival gangs are believed to be responsible for an outbreak of violence which has seen at least 12 killed and 20 injured since 1 January 2004.

That some members of the Jamaican public view the police as not committed to providing protection is a gross understatement. Many citizens in impoverished areas view the police as part of the problem. Unlawful killings by police officers continue at an alarming rate, along with frequent reports of unlawful detention of citizens. Yet the conviction of officers for this is very rare. Several investigative units have been formed in the past decade to little effect. Amnesty International has documented how the two units referred to in this extract, the Bureau of Special Investigations (BSI), which investigates police shootings and the Office of Professional Responsibility (OPR) which investigates all other incidents, lack specialist training, have failed to collect promptly or to preserve vital forensic evidence, and lack resources. Some reports of intimidation of witnesses have also been received. This Refusal letter is simplistic and shows a striking lack of knowledge about the complex and widespread nature of violence in Jamaica, particularly in the Kingston area.

A civilian body established in 1993 to oversee the investigative process has similar flaws and Amnesty International is concerned that it is unable or unwilling to undertake adequate investigations into police killings in Jamaica. The organisation rarely deploys its own extensive powers to recover and review evidence independently and is instead largely reliant on the inadequate investigations undertaken by the police. The unit is widely viewed as lacking credibility, independence and impartiality.

\section{Lack information about citizenship and statelessness}

Amnesty International is concerned that the implications of enforced return to Eritrea and Ethiopia of asylum applicants of mixed national origin are not acknowledged by the Home Office. This has very serious implications for asylum applicants, who are likely to face persecution on return to either of these countries.

\section{Eritrea}

Refusal letter extract, August 2002 The Secretary of State is aware that about 75,000 persons have been deported to Eritrea from Ethiopia during the past three years including those of mixed parentage, most have apparently been accepted in Eritrea as citizens despite the fact the (sic) only one fourth of them considers themselves to be Eritrean. Nevertheless the Eritrean government has offered considerable assistance to these people. He does not therefore consider that having one Ethiopian parent would have caused you to have suffered discrimination in Eritrea and this damaged your overall claim's credibility (sic).

\section{Amnesty International comment}

During the 1998-2000 war, Eritrea forced tens of thousands of Ethiopians to leave Eritrea and return to Ethiopia, mainly by denying them a livelihood in Eritrea. Some Ethiopians were detained (and some of them still are detained or 'disappeared') on suspicion of spying for Ethiopia or collaborating with the Ethiopian army while it occupied parts of Eritrea. These government attitudes towards people of full or part Ethiopian origin still prevail in the tense aftermath of the war. They form part of a much wider pattern of gross violations of basic human rights, including arbitrary detention and torture, in relation to growing demands by Eritrean activists, including many former liberation movement and government leaders, for democratic reforms and respect for human rights.

At the time of liberation and independence from Ethiopia in 1991, hardly any non-Eritrean Ethiopians were granted Eritrean citizenship, and dual Ethiopian and Eritrean nationality was not accepted. Ethiopians still reside in Eritrea as aliens (mostly migrant manual workers) but Eritrea does not accept back for permanent residence or naturalisation anyone of full or part Ethiopian origin. Eritrea will not give citizenship or a passport to anyone of part Ethiopian origin, and indeed requires of Eritreans, for the purpose of passports and travel to Eritrea, that they fully prove their Eritrean origin and confirm payment of obligatory development tax. If they are suspected of opposition to the government, they are very likely to be arbitrarily detained on return. Amnesty International can confirm that being half-Ethiopian in Eritrea, by either father or mother, might cause a person to be suspected of having secret Ethiopian government sympathies or contacts. This would put them at risk of human rights violations, amid current fears of a new outbreak of war between the two countries. Owing to the extensive activities of government security agents and informers, Ethiopian origin cannot be hidden. 


\section{Ethiopia}

\section{Refusal letter extract, August 2003}

It is acknowledged that large numbers of Ethiopians and Eritreans were expelled from each others' countries in the wake of the border dispute. However, the Ethiopian Government modified its policy regarding the detention and deportation of Eritreans and Ethiopians of Eritrean origin to Eritrea after it signed a cessation of hostilities agreement with Eritrea in 2000. In 2001 approximately 80,000 to 100,000 Eritreans and Ethiopians of Eritrean origin resided in the country. There are no updated statistics available at present. All Eritreans and Ethiopians of Eritrean origin are registered with the Government and hold identity cards and 6-month residence permits to gain access to hospitals and other public services (Ethiopia Country Assessment April 2003 - paragraph 6.101).

\section{Amnesty International comment}

Since the mass deportations of Eritreans in 1998-2000, Ethiopia has refused to issue or renew Ethiopian passports for anyone of full or part Eritrean origin and it would not accept back for residence or citizenship any person in those categories. It considers them to be Eritrean citizens, even though they may refuse this status.

In addition, the term 'Ethiopians of Eritrean origin' is problematic. All those of full or part Eritrean origin who were previously considered, or considered themselves to be, Ethiopian citizens, were stripped of their Ethiopian citizenship arbitrarily and without any legal recourse. Tens of thousands of them were deported in the first part of the 1998-2000 war, including children of a large number of 'mixed' families, which were forcibly split up. When deportations ended after massive international protests at this abuse and the way in which it was conducted, those who remained were ordered to register as aliens and given renewable six-month residence permits. They are not Ethiopian citizens. With fears of a new war between Ethiopia and Eritrea currently increasing, this Eritrean 'minority' in Ethiopia could be at risk of new human rights abuses and again accused of being enemy agents, and subjected to xenophobia and discrimination.

A new directive concerning Eritreans residing in Ethiopia was issued in January 2004 by the Security, Immigration and Refugee Affairs Authority in Addis Ababa. It is unclear what entitlement to Ethiopian citizenship there will be for those previously regarded as Eritrean citizens because they voted in the independence referendum, and those who were previously stripped of Ethiopian citizenship. It appears that the directive will not change the situation of those who fled the country to seek asylum or who have been outside Ethiopia for over a year.

\section{Ethiopia continued}

Refusal letter extract, August 2003 You speak Amharic and would not be readily identifiable as being of mixed race

\section{Amnesty International comment}

Despite its apparent certainty that applicants of mixed Ethiopian/Eritrean origin ['mixed national origin'] are not at risk on return to Ethiopia, the Home Office have stressed it will not be obvious to others that the applicant is of mixed 'race'. The term 'race' is misleading and inappropriate.

Those of full or part Eritrean origin who were born, or were long-term residents, in Ethiopia mostly speak Amharic and not all speak Tigrinya (the national language of Eritrea). Yet many are physically identifiable as being of Eritrean origin, through the greater Middle Eastern historical influences and contacts further north. They may be identifiable by their speech or cultural signifiers.

In addition, they are identifiable by the local urban neighbourhood association (Kebelle) authorities and neighbours' or citizens' knowledge of their identity, as well as other government and police records. Kebelles are the local administrative units which closely control the status and activities of residents, with particular reference to political issues. This would include control of resident Eritreans, when their redefined legal status and suspicions that they are agents of the Eritrean government.

\section{Lack of acknowledgement of complicity of the authorities with non-state agents} Amnesty International is concerned that the Home Office does not appear to comprehend the human rights situation in Colombia. This case concerned an asylum applicant who received threats and suffered attempts on his life from paramilitaries.

\section{Colombia}

\section{Refusal letter extract, March 2003}

The Secretary of State considers that the authorities of Colombia are capable of offering you effective protection. With regard to the offences committed against you, and the failure of the police to capture the perpetrators, the Secretary of State does not consider that the inability of the police to identify and apprehend such people can be construed as complicity in, or support for, such behaviour. He is aware that prosecutions are actively pursued through the courts when arrests are made.

The Secretary of State accepts that there are public order problems in Colombia, largely due to a number of terrorist groups which exist with the avowed intention 
of overthrowing the State, and that these problems are made more acute by drug traffickers and self-defence groups. However, the Secretary of State is aware that the Colombian government has taken genuine steps to address this issue and continues to respond positively to international concerns about the reported serious human rights violations committed by groups attempting to destabilise the country's democratic process. President Uribe, at his inauguration, announced what he called a 'State of Public Unrest'. He announced his intention to combat terrorism and gave the Security Forces extra powers to help them investigate and detain suspected terrorists.

\section{Amnesty International comment}

There are approximately 20 politically related killings a day in Colombia. Amnesty International is aware that in 2003 approximately 75 per cent or more of non-combat politically-related killings and forced disappearances were attributed to paramilitaries acting in conjunction with, or with the acquiescence of, the Colombian security forces. Almost eight per cent were attributed directly to the security forces. Amnesty International continues to document the continuing collusion between the armed forces and paramilitary groups, the consolidation of paramilitaries in heavily militarised areas and the failure of the authorities to end impunity of armed forces personnel implicated in human rights violations in conjunction with paramilitaries. Both the army and its paramilitary allies, and guerrilla forces kill people they label as enemy sympathisers. This is an integral part of their military strategy. The Office of the UN High Commissioner on Human Rights continues to document strong links between the armed forces and paramilitaries.

\section{Internal relocation}

Many refusal letters state that the applicant should have relocated within their country before fleeing to claim asylum abroad. This is complex for most claimants, and there are many issues to be considered with regard to the safety of the region for the particular applicant. ${ }^{14}$ The Asylum Policy Instructions on 'Internal Flight' ${ }^{\text {'s }}$ state that the applicant would have to show that relocation would be unduly harsh. Caseworkers are advised to consider a number of factors and adopt a 'common sense' approach to internal relocation. Internal relocation is a significant issue for the applicant, as the Asylum Policy Instructions demonstrate:

If the applicant has a well founded fear of persecution for a Convention reason in one part of his home country, and it is not reasonable to expect them to live in another part of that country, they should be granted asylum rather than another form of leave.

However, from a study of refusal letters shown to
Amnesty International in 2003, it is clear that the issues surrounding internal relocation are not considered sufficiently for individual applicants.

An example from Somalia shows that caseworkers can fail to follow the Asylum Policy Instructions in considering whether the quality of the internal protection meets basic norms of civil, political and socio-economic human rights. This applicant was a single female of the Marehan clan: ${ }^{16}$

\section{Somalia}

\section{Refusal letter extract, January 2003}

[The Secretary of State] considers that it is safe for you to return to Somalia. He is aware that members of the Marehan clan, part of the Darod clan family, were disadvantaged after President Siad Barre, a Marehan, was overthrown in 1991. However, the Secretary of State knows that Marehan family members have since been able to return to Mogadishu without fear of persecution, while Marehan control Gedo region and are safe in Puntland (which is dominated by the Majerteen, another Darod clan). Furthermore, the Secretary of State is aware that the Galgadud region, where Hawiye family clan are in the majority, is regarded as safe and stable, with no reports of clan fighting. The Secretary of State is therefore of the opinion that your claim for international protection is seriously diminished as a result.

\section{Amnesty International comment}

The fact that the applicant is a single woman without familial protection would place her at an increased risk of serious human rights violations on enforced return to any region in Somalia.

Apart from the general absence of rule of law and government in Mogadishu, there is no guaranteed safety for Marehan without the paid protection of warlords. Memories of Marehan oppression under the Siad Barre regime are strong, and equally the atrocities against Marehan by Hawiye when they drove out Siad Barre and his hated security forces and civilian supporters.

The home area of Marehan is the Gedo region, which is reportedly divided by conflict between rival Marehan factions and is very insecure.

Galgadud would not be safe for Marehan because they do not live there and relations between the majority Hawiye and Marehans are bitter. Marehans would have no clan protection in Galgadud and far from being 'safe and stable', it lacks any government or administration that can guarantee rights.

There are few Marehan in Puntland, since it was not a region for Marehan settlement, despite their being members of the same Darod clan-family as the dominant clan in Puntland. 
Asylum Policy Instructions also tell caseworkers to consider whether the applicant [would] be required to encounter great physical danger in travelling to or staying in another part of the country. This applicant was a single, middle-aged, mentally vulnerable woman from Afghanistan:

\section{Afghanistan}

Refusal letter extract, November 2002 There is general freedom of movement within Afghanistan, which will allow you to move internally to any area where your ethnic group does not constitute a minority and where you would not face such difficulties. It would not be unreasonable or unduly harsh to expect you to do so.

\section{Amnesty International comment}

Amnesty International believes that the internal relocation within Afghanistan of a woman of this profile, with no male protection, would be 'unreasonable and unduly harsh'. ${ }^{17}$ Amnesty International is surprised by the Home Office assertion that there is 'general freedom of movement' in Afghanistan when up to two-thirds of the country is insecure, and there is continual factional fighting, targeted persecution of minorities and the continued presence of landmines and unexploded ordnance.

Asylum Policy Instructions on internal relocation also instruct caseworkers to consider whether the 'safe' part of the country is reasonably accessible and whether the applicant would be required to undergo undue hardship in travelling or staying there. This applicant was from Kinshasa, in Democratic Republic of Congo:

\section{Democratic Republic of Congo}

Refusal letter extract, February 2001 The fact that fighting was taking place in this area is irrelevant, the Secretary of State can reasonably expected (sic) you to go to Kisangani.

\section{Amnesty International comment}

Kisangani, one of DRC's largest cities, was the scene of bitter fighting between Rwandese and Ugandan government forces in August 1999 and May/June 2000. Hundreds of civilians were killed in the crossfire in the streets, or as they sought shelter in their homes, schools and workplaces. In May 2002, around 100 people were extrajudicially executed in Kisangani following a failed mutiny against the RCD-Goma (a Rwandese-backed armed political group) which controls the city. Headless bodies were tied up in sacks and thrown in the river.

Throughout the DRC conflict - from August 1998 to the present day - Kisangani has been the scene of constant violations of human rights. Cases of unlawful killings, rape, torture and ill-treatment have been, and continue to be, regularly reported. The RCD-Goma authorities have also responded with violence to peaceful political dissent - such as strikes and demonstrations by Kisangani's civilian population. The city also suffered deprivation of food and other essentials, owing to the closure of the Congo River (only recently reopened to commercial traffic) and to the fact that the city and RCD-Goma enclave was effectively cut off from its surrounding agricultural hinterland which had therefore to be supplied mainly by air. Amnesty International considers it is unreasonable in the extreme to suggest that any person could return safely to the city. Even today, despite peace agreements and the inauguration of a transitional power-sharing government, the situation in Kisangani remains tense and unpredictable. 


\section{4.}

\section{A negative culture}

\section{Unreasonable assertions about individual credibility}

Since the examiner's conclusion on the facts of the case and his personal impression of the applicant will lead to a decision that affects human lives, he must apply the criteria in a spirit of justice and understanding and his judgement should not, of course, be influenced by the personal consideration that the applicant may be an 'undeserving case"1

- UNHCR Handbook

Amnesty International is concerned about the frequency with which Home Office caseworkers make unreasoned and unjustifiable assertions about asylum applicants which cast doubt on the applicant's individual credibility. These usually appear in Refusal letters after more general country information has been dealt with. Where less country information is available to caseworkers, it is probable that individual credibility will be pursued more vigorously. A research study commissioned by the Home Office found that:

Caseworkers may be advised by senior caseworkers to deal with a claim from 'a different angle' when the necessary COI [Country of Origin information] is unavailable, for example by refusing on credibility grounds. ${ }^{2}$

At appeal, it is often the case that an applicant who has good legal representation will submit a written statement and testimony which further explains events that were doubted by the Home Office, and makes sense of the issue that led to an outright denial of credibility. The Asylum Policy Instructions to Home Office caseworkers state:

Where representations are made, any new issues not previously taken into account should be given full consideration in the light of all earlier information and a response given so that the Immigration Appellate Authority (IAA) will have an opportunity to consider them at the appeal hearing. Early consideration of new evidence may avoid having an appeal hearing adjourned by the appellate authority for further consideration by IND.

The original decision should not be withdrawn pending consideration of further representations. ${ }^{3}$ (emphasis IND)

Amnesty International believes that there is no sufficient mechanism in place for adequate reconsideration of decisions to refuse asylum in cases where credibility issues or misunderstandings by the Home Office have subsequently been adequately explained and clarified by the applicant. The Asylum Policy Instructions to caseworkers encourage them to limit the consideration of post-decision submissions to new evidence, and implies that caseworkers in most cases should prepare to proceed to appeal. The unnecessary progression of certain cases to appeal leads to further costs in terms of public funds.

Unreasonable assertions about individual credibility in Refusal letters have continued over recent years, despite so-called 'advances' claimed by the Home Office. ${ }^{4}$ Amnesty International believes that in cases in which the credibility of an applicant has been unfairly denied unsupported by adequate reasons or the citation of objective sources, the Home Office should undertake to reconsider the asylum claim substantively. The quality of Home Office decision making on asylum claims will only improve when a sufficient mechanism for such monitoring is in place.

\section{Denials of credibility in Home Office Refusal letters}

Amnesty International believes that a 'checklist' approach to issues of credibility informs a negative culture of decision making, which is often based on 'catching applicants out' rather than investigating the substance of their claims. Because issues of credibility raised are often 'non-issues' or are badly reasoned, this system is no better at identifying 'noncredible' asylum claims than it is at deciphering 'genuine' ones.

Home Office Refusal letters often make assumptions about how people would behave in a certain situation, for example how a regime official would react to the offer of a bribe or how a political individual would respond to a warning from the authorities in their country. This appears to be based on nothing more than the sensibilities of the individual caseworker themselves, in accordance with their own view of what would constitute 'rational' behaviour in a given situation.

Refusal letters may also cast doubt on the credibility of an applicant when there are any minor 
discrepancies in his or her account. In doing so, they ignore the wealth of objective information which shows that minor discrepancies in the accounts given by asylum seekers are to be expected, and in some cases actually support the view that an applicant is telling the truth about his or her experiences. ${ }^{5}$

It is also possible that insufficiently trained Home Office caseworkers, without adequate time to prepare for asylum interviews, are not in control of their material during the interview and spot apparent discrepancies later on, which are then inserted into the Refusal letter. In many cases, Refusal letters appear to lack what is referred to in the UNHCR Handbook on Procedures and Criteria for Determining Refugee Status as:

An understanding of the particular situation of the applicant and of the human factors involved ${ }^{6}$

The result is many Refusal letters that are illogical in content. Yet for those to whom they are addressed, the effect of their dismissive tone can be devastating. It is implied, or sometimes explicitly stated in Refusal letters, that the applicant is 'bolstering' or 'fabricating' their asylum claim to obtain refugee status. There is no sign anywhere of the presumption of 'benefit of the doubt', a principle which governs the guidance given in the UNHCR Handbook ${ }^{7}$ to which Home Office caseworkers are encouraged to refer by their own Asylum Policy Instructions. ${ }^{8}$

Many professionals who work with asylum seekers are often confounded by the insertion of paragraphs in Refusal letters relating to credibility which do not appear to fit the applicant's claim properly, or which simply appear to be blatantly subjective.

This section of the study will examine two main issues which the Home Office uses to contest the credibility of individual asylum seekers in Refusal letters:

1. Doubting the asylum account

Aspects of the applicant's claim are denied on credibility grounds without adequate reasons being provided.

2. The history of departure and arrival in the UK The asylum claim is doubted on the basis of immigration issues which are not directly related to the applicant's need for international protection.

\section{Doubting the asylum account}

It is clear from the UNHCR Handbook that an asylum applicant can experience difficulties in relaying his or her account:

It should be recalled that an applicant for refugee

status is normally in a particularly vulnerable situation.

He finds himself in an alien environment and may

experience serious difficulties, technological and psychological, in submitting his case to the authorities of a foreign country, often in a language not his own ${ }^{9}$
Before considering the credibility of the account of an asylum applicant, it is useful to bear this in mind: $:^{10}$

It is not in the nature of repressive societies to behave reasonably, the strange or unusual cannot be dismissed as incredible or improbable particularly if there is supporting material of similar accounts in the relevant human rights literature and [decision makers] should be constantly on their guard to avoid implicitly recharacterising the nature of the risk based on (their) own perceptions of reasonability.

\section{1 a) Perceived discrepancies in the account}

Caseworkers often refuse asylum applications because of discrepancies between accounts given during the asylum process. The Asylum Policy Instructions to Home Office caseworkers state:

Where the applicant has been given no opportunity to explain inconsistencies, care should be taken about using the inconsistencies to question credibility. ${ }^{11}$

Nonetheless, where minor discrepancies are identified, the Home Office will often use them to discredit the asylum account as a whole. This can apply where an applicant has been given no opportunity to provide an explanation or further clarification of events at his or her asylum interview.

Home Office caseworkers have an opportunity at the asylum interview to clarify issues of credibility by asking further questions. Caseworkers are encouraged to do this throughout the Home Office Asylum Policy Instructions which relate to interviewing protocol. ${ }^{12}$

However, it is often the case that 'discrepancies' between the initial Statement of Evidence form (SEF) and the asylum interview are given as a reason for denying credibility in Refusal letters. This indicates that Home Office caseworkers can perceive the interview as an opportunity to demonstrate that an applicant is 'inconsistent' and therefore 'not credible', rather than an opportunity to investigate thoroughly all the aspects of the applicant's case. Mark Henderson, in the Best Practice Guide to Asylum and Human Rights Appeals, states:

Very often, the claimant will be given no opportunity to comment on a perceived inconsistency between answers during the interview. The answers will simply be stored up for presentation in the refusal letter as unexplained discrepancies. ${ }^{13}$

\section{China}

Refusal letter extract, February 2003 Within your Statement of Evidence Form (SEF), you claim that in February 2002, a month after the alleged execution of your parents, your headmaster 
informed you that you had to leave the school as a result of your parents' situation. Yet, in response to question 1.4 of the Screening interview, you claim to have been in education until 2001 when you were expelled by your headmaster. The Secretary of State has noted this discrepancy and as such, he finds your account lacking in conviction.

\section{Amnesty International comment}

The Home Office has failed to consider cultural issues in this case, such as whether this applicant was using the Chinese calendar. If so, the Chinese New Year 2002 began on 12 February. ${ }^{14}$

Even if the applicant was not referring to the Chinese calendar, the discrepancy would be minimal and it should be explained why it should have a bearing on the applicant's account as a whole. There appears to be a complete lack of consideration of this applicant's age or the trauma that must be attached to discussion of his parents' death.

- This asylum applicant entered the UK as an unaccompanied minor and was aged 15 at the time when he states that this incident happened. Minors whose age is not disputed and who cannot be returned to their country of origin, are granted discretionary leave to remain until they are 18 years old.

The following extract represents an example of how apparent 'discrepancies' are often not queried during the interview, and are then presented as 'reasons for refusal' in Refusal letters:

\section{Ethiopia}

Refusal letter extract, October 2002

The Secretary of State notes that there are significant differences between your various accounts, and that these cast doubt on the credibility of your claim. In your statement you claimed that your husband had kept the documents about [organisation] in the house. However when you were interviewed on [date] September 2002, when asked about the documents, you claimed that your husband had hidden the documents in the back yard.

\section{Amnesty International comment}

This indicates a 'searching' for discrepancies by the Home Office, rather than an investigative approach. It is clear that references to a person's house could include the back yard - even without difficulties that may have arisen in interpretation at this interview. The applicant's response to the Refusal letter stated: [The documents] were kept in our house. Specifically they were kept in the backyard in the garden.
At appeal at the Immigration Appellate Authority (IAA), the Adjudicator found that: [The] refusal letter has not been prepared as carefully as it ought to have been. -I find that nothing of significance turns upon the Appellant's description of the house as including the garden and back yard, and that there is no discrepancy there.

Refusal letters can assert denials of credibility with regard to discrepancies that are not central to the asylum claim, and therefore should have no bearing upon it. ${ }^{15}$

\section{Eritrea}

\section{Refusal letter extract, March 2001}

The Secretary of State also notes that there are significant differences between your various accounts, and that these cast doubts on the credibility of your claim. For instance, in your Statement of Evidence Form (SEF) you stated that you were in hiding at your friend's house for 4 days but in your Asylum Interview this was reduced to 3 .

\section{Amnesty International comment}

Not only is this a minor discrepancy, which could possibly be explained and clarified, but it concerns a time period that would have been frightening and uncertain for the applicant, making a confusion over the exact number of days understandable. In addition, it is not explained here why the number of days in hiding is central to the applicant's claim for asylum in the UK.

\section{Eritrea continued}

\section{Refusal letter, March 2001}

At the end of the Asylum Interview your representatives stated that the dates throughout the interview may not be the same as those in your SEF as the Ethiopian calendar was used. The Secretary of State accepts this but notes that you used the European calendar to say when you left Sudan, that is on 28th January 2001 as it is the same date that you arrived in the United Kingdom. Such inconsistency casts doubt on your personal veracity and consequently the credibility of your claim. (emphasis Al)

\section{Amnesty International comment}

It is clear to Amnesty International - as it is to any organisation that works with asylum seekers - that the date of arrival in the country is clearly stamped on an applicant's paperwork, and referred to throughout their case. It would therefore be easier for an asylum applicant to refer to it in 'European' terms. This does not 
mean that an applicant could then be expected to be able to deal uniformly with all other dates relating to their case in this way.

This problem indicates a pursuit of the refusal of asylum claims as an objective - rather than a line of enquiry that investigates all the facts and focuses on the individual applicant's need for international protection.

For example, under the heading 'Discrepancies' in the Asylum Policy Instructions to Caseworkers, the following standard paragraph is provided:

The Secretary of State noted that there were significant differences between your various accounts, and that these cast doubt on the credibility of your claim. He considered that, had the events in your later account occurred as you claimed, it was reasonable to expect that you would have mentioned them at the earliest opportunity. ${ }^{16}$

This paragraph is intended to apply to any case in which discrepancies arise. Although caseworkers are encouraged to alter standard paragraphs to include specific information about individual discrepancies arising in each case, there is no warning to caseworkers to be careful about the specifics of the case - to ensure that the discrepancies they are dealing with actually fit the reasoning of the standard paragraph.

\section{$1 \mathrm{~b})$ Assertions about motivation and actions of perpetrators of human rights violations}

It has already been seen in this report how the Home Office makes blanket denials of human rights violations by asserting that the authorities of a specific country do not 'condone' or 'sanction' such practices. ${ }^{17}$ However, assertions about the motivations and actions of those who commit human rights violations in specific situations also arise in Home Office Refusal letters. These assertions are often made by caseworkers and may reflect a lack of understanding or experience of the country concerned, and therefore no ability to place events described by asylum applicants within their specific cultural or political context.

\section{Jamaica}

\section{Refusal letter extract, May 2002}

You claimed that the gun men came twice. You claimed that they had said that they will come next day (sic) and so you fled to a friend's place with the children. However, the Secretary of State considered that the gun men would not have taken a chance if you had previously escaped from them. He also noted that there was a group of gun men and considered that they could have easily kidnapped you and the children at the time.

\section{Amnesty International comment}

No objective sources are cited to support this assumption. In numerous areas of Kingston and other regions in Jamaica, gunmen operate by attempting to inflict terror on the local population. It is not unusual for gunmen to delay carrying out threats immediately and return to their victims later. Often the strategies of Jamaican 'gangsters' are to create fear and uncertainty in their victims. Threats to carry out violence at a later date are commonplace and are often carried out.

\section{Algeria}

Refusal letter extract, February 2003 You have claimed that you received phone calls from the man whom you recognised at the checkpoint. You have claimed that the phone calls occurred several times a day until you left Algeria, approximately one month later. You claim that you answered only one of these calls and the man threatened you and asked you for money... The Secretary of State does not believe that if the Islamic militants wanted you for running away from them at the checkpoint or wanted money from you as a bribe, that they would simply call you several times a day in the hope that you would answer the phone and pay their demands. The Secretary of State believes that these men would have visited your home, searched your home, searched for you at friends and relatives houses and harassed and intimidated your family until they located you. Yet none of this happened.

\section{Amnesty International comment}

This is a subjective judgement, and one that is wrongly based upon the capabilities of perpetrators rather than on accurate information about their methods. Since the emergence of armed groups in Algeria in 1992, Amnesty International has received consistent reports of armed groups issuing threats in the form of letters, telephone calls and in person to extort money or services. Threats over the telephone sometimes appear to have been used when a strong security presence in the area prevented the armed group visiting the home of the victim in person

\section{Iran}

Refusal letter extract, July 2003 The Secretary of State [is led] to disbelieve that you were being targeted by the Basij. The Secretary of State is strengthened in this view by your claim that 
despite the local Basij boys being aware that you were a homosexual they did not tell your parents. The Secretary of State does not find it credible that the Basij would not make your parents aware that you were a homosexual. The Secretary of State is of the opinion that the Basij would feel duty bound to notify your parents of your sexuality and the fact that they did not leads the Secretary of State to disbelieve your claim to have been targeted by the Basij

\section{Amnesty International comment}

This is an example of how asylum applicants are often made to feel that they should explain not only their own actions and motivations, but those of the authorities or agents that they have fled from. The source of this information about the Basiji is not cited and it is framed as the 'opinion' of the Secretary of State.

The Basiji, or 'mobilisation', forces in Iran were originally volunteers during the Iran/Iraq war between 1980 and 1988. They operate in local groups and their behaviour and actions vary according to the region they are based in, the social structure of their neighbourhood and the mosque or clerics they are associated with. Basiji forces often commit acts of extreme violence in carrying out the perceived wishes of the 'Supreme Leader' of Iran. They are not governed by any centralised agency or code of practice or duty, and they enjoy de facto impunity. Because Basiji forces have a non-formal structure, their response to perceived crimes, such as homosexual activity, cannot be predicted.

\section{1 c) Assumptions about the political motivations of asylum applicants}

Many asylum seekers flee countries where any expression of opinion in opposition to the existing regime is banned and perceived dissidents are ruthlessly punished. Punishment can include detention, torture and loss of life. Nonetheless, Amnesty International has been aware since its foundation, that exceptional individuals continue to strive for political change in such countries, despite the threat to their lives and the lives of their families. This quality is applauded when it is presented in a biographical film, book or television documentary but appears to be entirely misunderstood when presented in the form of an asylum claim. The Home Office makes assumptions about asylum applicants that reveal a total lack of understanding of how people live under restrictive regimes - and the strength of their political motivation when their rights and freedom of expression are threatened or denied.

\section{Iran}

Refusal letter extract, October 2001 You state that you were first detained when aged 13 years, for several months, because you were accused of membership of 'Fadayeed Khalq'(sic). The Secretary of State would have expected that if this event had in fact occurred, at such a young age, the associated trauma would have been sufficient to prevent your further involvement in events likely to bring you to the attention of the authorities.

- The usual spelling is Fedayin-e Khalq

\section{Amnesty International comment}

Amnesty International is aware of many cases of political activists inside and outside Iran who have continued to express opposition to state policies, government or state structure after having suffered detention and torture or the punishment of family members. The student activist Ahmed Batebi - a political prisoner - who was arrested during the July 1999 demonstrations in Tehran, was kept in incommunicado detention where he reportedly suffered ill-treatment prior to being sentenced to death in a manifestly unfair trial. His death sentence was later commuted to 15 and later 10, years. In October 2003 he was granted 'temporary release' on medical grounds. While on release, he met the United Nations Special Rapporteur on the Right to Freedom of Opinion and Expression, reportedly to discuss prison conditions. Immediately following this meeting he was re-arrested and accused of breaking the terms of his temporary release. $\mathrm{He}$ is now serving the remainder of his original sentence. ${ }^{18}$

\section{Bhutan}

Refusal letter extract, August 2003 If you were in genuine fear of the authorities due to your political activities, you would not have continued to associate with people who might bring you to the adverse attention of the authorities.

\section{Amnesty International comment} In countries such as Bhutan with repressive regimes, opposing political activities are always carried out in a climate of fear. Political activists - referred to by the government in Bhutan as 'anti-nationals' - continue to face discrimination and danger of arrest, exile or imprisonment. Nevertheless human rights defenders and political activists continue to publicise and oppose the measures and practices adopted by the government which they interpret to be oppressive or discriminatory.

Amnesty International is aware that, traumatic as they often are, unjust actions by the authorities of a country can result in a strengthened resolve of 
individuals who continue to fight the system in place. Also individuals react differently to threats some shrink, some fail to register the threat, and some are galvanised into action.

\section{$1 \mathrm{~d})$ Assumptions about the actions and decisions of asylum applicants}

Where asylum applicants have made decisions or taken actions which diverge from those that the Home Office would consider wise or rational, denials of credibility can be put forward in Refusal letters which have no basis whatever in fact or in law.

\section{Democratic Republic of Congo}

\section{Refusal letter extract, March 2002}

The Secretary of State also considers it unlikely that you would leave the DRC so quickly after the alleged attack without finding out what had happened to your family. He notes that you left a partner and child in DRC and does not accept that you would have done this if their lives were in danger and the fact that you have left them behind undermines your claim that they were also attacked.

\section{Amnesty International comment}

This applicant claimed that he fled from the family home when Congolese soldiers shot and killed his father and raped his mother, wife and sister in front of him. The Refusal letter lacks an understanding of the actions of people in desperate circumstances and the effects of traumatic experience on individuals. It incorporates an implied moral judgement that is irrelevant to the applicant's claim for protection.

The Home Office's Asylum Policy Directions to caseworkers state:

The mere fact that a family have been left in the country of origin can not be used as a reason for the refusal of asylum. - Before any adverse judgements of this nature are made, caseworkers should ensure that the applicant has been asked to explain the circumstances. ${ }^{19}$

\section{Uganda}

\section{Refusal letter extract, April 2002}

You also claimed you had five children. However upon your release from detention you made no attempt to find them before you left the country. You seemed quite happy with the idea that they all got separated. You were quite content to make good with the only child that you claimed was kept by neighbours. Again it is unlikely that the neighbours would keep your child for an entire year after the rest of her family had deserted her and compounded with the fact that you also had an uncle who you were in obvious contact with (sic).

\section{Amnesty International comment}

This paragraph is laden with subjective judgements. Implicit is a suggestion that the applicant is a 'bad' mother, although even if she were proved to be such, that would be irrelevant to her asylum claim (in fact, three of this applicant's children were adults and not living with her $-\mathrm{a}$ fourth child went missing).

The conclusion that she should rely upon her uncle to accommodate her child rather than her neighbour has no basis in fact and is not objectively sourced or explained. With regard to the specific situation in Uganda, Amnesty International is aware that families in Uganda have in numerous cases taken in neighbours' or relatives' children during wars and other catastrophic events.

\section{1 e) Assumptions about the actions of other people mentioned in the asylum account}

Another problem for some asylum applicants is proving that other individuals would take sacrificial or risky actions to help them, although all through history there have been examples of individuals who have been prepared to take risks to help others. The Home Office has an openly cynical attitude about this but does not provide adequate reasons for it.

\section{Uganda}

Refusal letter extract, January 2003 The Secretary of State looks at the manner of your escape from hospital. You have stated that your cousin who also happened to be a doctor at the hospital helped you to flee. He is of the view that if your cousin had overheard that you were going to be killed, he would not have played a role in your escape which invariably would implicate himself (sic).

\section{Amnesty International comment} Amnesty International is aware of many family members who have risked their own lives in order to save their relatives. This reasoning lacks any objective basis.

\section{Ethiopia}

\section{Refusal letter, October 2002}

The Secretary of State has further considered your claim that whilst in detention that one of the guards had asked what he could do for you. You 
claim that you had given your parents address to him, and to inform them (sic) that you were in prison. The Secretary of State finds it particularly difficult to accept that this guard would have asked that question, or more importantly would have helped you in such a way. As such he has doubts about your credibility.

\section{Amnesty International comment}

No explanation is given of the reasoning behind this conclusion. The applicant claimed that she was tortured and raped on several occasions by three officers and was helped by a guard who got a message to her parents about where she was. In her response to the Refusal letter for her appeal, she described this as follows: One of the guards in the prison saw that I was not well due to the treatment which I was receiving in the prison. He volunteered to help me out of the goodness of his heart. I asked him to contact my relatives and arrangements were made for me to get out of the prison. I do not believe that the guard was bribed and I do not believe that he was [from my ethnic group] I believe that his humanity prevailed upon him when he saw my condition.

\section{$1 \mathrm{f})$ Perception of events in the asylum account}

Denials of an applicant's credibility can also be based on caseworkers' own perceptions of events which are described in the asylum account. These often indicate a lack of accurate country information, which is an obstacle to quality decision making on every aspect of asylum claims.

\section{Syria}

\section{Refusal letter extract, December 2000}

The Secretary of State is aware of your statement that upon return to your home you found the door still locked but the flat ransacked, however he doubts the credibility of this claim as he finds it difficult to accept that if this was the case how would anyone be able to gain access without a key and also the fact that if someone was going to break in why they would take the trouble to lock the door behind them (sic)

\section{Amnesty International comment}

The applicant's statement reads:

I found our flat had been ransacked, our papers, tapes and books had been rifled through. It seemed as if they had been searching for documents and anything might be used in evidence against me. I believe that the security police did this. Since the doors of the flat were still locked, it was not a burglary. I did not want to involve the neighbours by asking them if they noticed if anybody had got into the flat. They were frightened of the authorities and so wanted to distance themselves from us. I was sure that sooner or later the security police would come back. I was psychologically disturbed by what happened.

This account is consistent with Amnesty International's knowledge of the behaviour of the security forces in Syria. The method of break-in may be intended to prevent others from entering the room so that the applicant discovers it first; to make it obvious that it was not a simple burglary and to create confusion in the individual's mind. Ultimately the Syrian security forces intend to indicate to individuals that they are all-powerful and able to do whatever they want.

\section{1g) Escape from detention and release by payment of bribe}

Denials of credibility with regard to events described by asylum applicants are perhaps most prevalent in relation to claimed escape from detention. According to the Home Office Refusal letters that Amnesty International has received, there is no such thing as escape from detention in any country. Whether the escape is self-perpetrated or assisted, the Home Office is convinced that it cannot have happened and the claim that it has happened casts doubt on the claim that an asylum applicant was in detention at all.

It is true that many accounts of escape from detention seem improbable, owing to the combination of luck, accurate timing, and the help, in some cases, of unlikely individuals. However, Amnesty International is aware that escapes can and do happen in detention systems throughout the world - from the very sophisticated to the most basic. In countries with unstable economies, systems of bribery which enable escape are the norm and family members can pay large sums of money to obtain the freedom of a detainee or prisoner.

One reason that 'escape' is misunderstood by the Home Office relates to its lack of adequate country information. Often Refusal letters appear to assume the conditions that they would expect in UK prisons. However, even in UK prisons, where security is routinely maintained, escapes are known to happen.

\section{Uganda}

Refusal letter extract, February 2003

The Secretary of State has noted that you claim to have escaped from detention when you were being transferred to another prison. You claim that the vehicle you were in was involved in an accident and 
you woke up in a hospital and then you escaped from the hospital before the government forces arrived. The Secretary of State is of the opinion that if you had been of significant interest to the Ugandan authorities you would not have been able to escape with such ease because there would have been more stringent security in place. The fact that you were able to escape with such ease leads the Secretary of State to further consider that your detention did not take place as you have claimed.

\section{Amnesty International comment}

Security facilities provided in the public hospitals in Uganda are under-resourced. Given the general circumstances within which the police and numerous security agencies function, and their lack of coordination in Uganda, it is not possible to deny, without specific reasons, the possibility of escape.

Decision-makers are at every stage in the process entitled to disregard information that they find implausible. However, to merely state that they 'don't believe' that conditions might exist in foreign prisons which could enable escape - without referring to objective information on conditions of detention in those countries - leads to unsubstantiated assertions and therefore unjustified decisions. Amnesty International believes that if an escape is considered implausible, the asylum applicant should be permitted to explain the situation further before a Refusal letter is issued.

Refusal letters also deny the credibility of accounts of bribery to secure escape or 'release' from detention. Amnesty International has seen letters which deny systems of bribery in countries where corruption is known to exist at every level of society and economic need is such that officials can and do accept bribes in spite of the risks. In Refusal letters, the denial of the possibility of bribery is always stated in terms which imply that the applicant is lying.

\section{Libya}

\section{Refusal letter extract, January 2003}

You have claimed that the guard where you were detained aided you in your escape from the prison. The Secretary of State is of the considered opinion that an officer within a government role would not so openly jeopardise his position of responsibility, especially considering the way you escaped could be so easily traced back to the guard who was on duty at that time.

\section{Amnesty International comment}

The source for this belief is not stated, nor is an explanation of the Secretary of State's 'opinion' on the considerable risk faced by the guard who enabled this applicant to escape. Libya is a country where systems of bribery operate at every level.

\section{1 i) The credibility of children}

Another issue that is used by the Home Office to deny the credibility of asylum claims as a whole is the expectation that unaccompanied asylum seekers who state that they are minors (under 18 years of age) should provide documentary proof. This can seriously disadvantage minor applicants throughout their claim for asylum and beyond. A child whose age is disputed can be detained as an adult. The UNHCR and Amnesty International both oppose the detention of children and are concerned that detention detrimentally affects their development.

Children whose age is disputed can also be denied support and accommodation by both social services, who support and accommodate minor asylum seekers, and the National Asylum Support Service (NASS) ${ }^{20}$ which caters for adult asylum seekers. This can result in destitution.

The identification documents of disputed minors often state before the birthdate, 'claims to be' which may stigmatise them and indicate to other people that they are not to be trusted. Where the applicant's statement of age is not believed, this will ensure that the credibility of their claim to need protection will also be doubted.

The denial of minor status to child asylum applicants is an almost uniform approach taken by the Home Office with regard to teenagers who do not fit their picture of what a person under the age of 18 should look like. Tall children, or those who appear to an Immigration Officer to look older than 18, can therefore be denied their rights as children under UK law. Amnesty International is concerned that the judgement of a person's age may soon be enshrined in statutory immigration and asylum law as one that can be made by medically unqualified officials. ${ }^{21}$ The UNHCR Guidelines on Policies and Procedures in dealing with Unaccompanied Children Seeking Asylum, state that:

If an assessment of the child's age is necessary, the following considerations should be noted:

a) Such an assessment should take into account not only the physical appearance of the child but also his/her psychological maturity

b) When scientific procedures are used in order to determine the age of the child, margins of error should be allowed. Such methods must be safe and respect human dignity

c) The child should be given the benefit of the doubt if the exact age is uncertain. ${ }^{22}$

The UNHCR Guidelines are not heeded by the Home Office: 


\section{Rwanda}

Refusal letter extract, November 2002 The Secretary of State has also noted when you made your application for asylum, you claimed that your date of birth is [date] 1985. However, you have failed to produce any evidence to substantiate this claim. Although you claimed to be a minor your physical appearance before the Immigration Officer suggested that you were over eighteen. In the absence of any evidence to the contrary the Secretary of State does not accept you are a minor and is satisfied you should be treated as an adult

\section{Amnesty International comment}

It is not clear what documentary evidence is expected to 'substantiate' the date of this applicant's birth. Many asylum seekers leave their country of origin in a desperate hurry and do not have their own passport. Even if a minor applicant has a birth certificate, they would be unlikely to take it with them, or to be aware that it would be required in the UK.

In Rwanda, birth certificates are issued only to those born in a hospital. Many Rwandans are not. Rwandans are more likely to have baptismal certificates, although the genocide and destruction of many churches could have led to their loss.

\section{Rwanda continued}

Refusal letter extract, November 2002 The Secretary of State has given due consideration to the documents you have submitted, from the [name] Asylum Organisation [dated] Psychological Report, [dated], of a Consultant Clinical Psychologist of the Traumatic Stress Service, commenting on their opinions as to your age, but in view of neither party being specifically qualified in child development, he is not prepared to accept their comments as corroboration of your age

\section{Amnesty International comment}

Nonetheless, the Home Office is prepared to accept the opinion of an Immigration Officer who is not medically qualified at all, on the basis of his or her view of this applicant's 'physical appearance'. Amnesty International believes that this is unacceptable and that the concerns of a child should always be paramount. Where credibility issues arise, children should be afforded the 'benefit of the doubt'.

\section{The history of departure and arrival in the UK}

In many cases, the Home Office uses the method of departure from the country of origin, and/or method of entry into the UK, to deny the credibility of the asylum claim as a whole.

Amnesty International is concerned about the increasing reliance on circumstances relating to departure and entry to dispute the merits of individual asylum claims. ${ }^{23}$ The notion that methods of departure and arrival in all cases cast doubt on the need of an asylum seeker for international protection is illogical unless it can be directly related to the content of the claim itself. Home Office Refusal letters indicate that this is rarely the case.

Departure from the country of origin is in most cases an extremely harrowing experience when a person is fleeing from a life-threatening situation and there is little or no possibility of return. Asylum seekers, with the exception of refugees 'sur place ${ }^{24}$ usually leave their countries in a state of hurried distress, often without the chance to gather up personal possessions or say goodbye to loved ones.

The government has introduced a range of measures to prevent access to UK territory. However, Amnesty International believes that visa requirements, carriers' sanctions and other obstacles make it almost impossible for asylum seekers legally to enter the UK and do not discriminate between those fleeing persecution and others. The government has accepted that asylum applicants may find it necessary to use deception to facilitate their departure from their country of origin.

Many asylum seekers are able to leave only with the help of an 'agent', who is paid by themselves or their family to smuggle them out of the country, or otherwise to depart through normal immigration channels by resorting to the use of false documentation. This is necessary for the majority of asylum seekers, who would be unable to obtain valid travel documents from the authorities in their country of origin for the very same reason they are fleeing for safety. According to the UNHCR:

Given the extensive legislative and other measures states have in place in order to 'legally' access European territory, it is not surprising that many genuine asylum seekers would be obliged to resort to illegal or irregular means to enter a country. Inconsistencies concerning a person's travel route may then be offered in order to protect the identity of the individuals who provided assistance, or to safeguard the travel route for future asylum seekers or to avoid return to a third country. ${ }^{25}$

Agents vary in their behaviour and motivations, but whatever the circumstances, the act of obtaining the assistance of an agent is, literally, the act of putting your life in another person's hands. The Home Office does not appear to take this into account when considering asylum accounts involving payment of agents. 


\section{Ivory Coast}

\section{Refusal letter extract, February 2003}

You have also claimed to have bribed a man who you took to be someone who worked on ships to help you escape to safety. You have claimed to have been previously afraid to take out the money you had found in front of other people: the Secretary of State therefore finds it to be implausible that you would show the money to a perfect stranger, even if you thought he could obtain access to a ship for you. He therefore believes that this part of your account calls the remainder of it further into question.

\section{Amnesty International comment}

To show money to a person to whom you are about to give it, is very different from showing money to a person who will not benefit from it. This takes no account of human relationships, financial transactions and people's ability to judge the response of others in a situation. It also makes no allowance for the fact that this applicant was probably taking a desperate chance in order to flee his country.

More important, it is not explained here exactly why the doubt that he would show this man his money is significant to his fear of persecution in his country of origin

\section{Timing of departure from the country of origin}

Refusal letters deny the credibility of asylum applicants on the basis that they did not leave their country at an earlier time. This approach takes no account of the difficulties experienced by asylum seekers who may have to raise funds to pay an agent to organise their passage out of a country; obtain necessary false travel documents to be able to depart without being apprehended; or remain in hiding until their route of departure is arranged. Even those who are able to leave through regular immigration channels on their own passport will have to make arrangements for their departure. They may have to ensure the safety of their remaining family, or sell property or belongings to fund their journey.

UNHCR guidelines acknowledge the different methods of departure of asylum seekers:

One person may make an impulsive decision to escape; another may carefully plan his departure. ${ }^{26}$

However, the Home Office Asylum Policy Instructions (APIs) to caseworkers on the composition of Refusal letters offer the following 'fill-the-gaps' paragraph under the heading 'Delay leaving home country':

Further doubts as to your alleged fear of persecution can be drawn from the fact that you did not leave
[COUNTRY] until [DATE]. The Secretary of State holds the view that if your fear of persecution by the [] authorities was genuine you would have left [] at the earliest opportunity and the fact that you did not casts doubt on your credibility. ${ }^{27}$

This standard paragraph indicates a lack of appreciation by the Home Office of the different circumstances of applicants from various countries and how they may affect their ability to depart. Amnesty International believes that this approach is symptomatic of a general lack of understanding of country information by the Home Office. This makes it ill-equipped to decide upon the individual merits of asylum claims.

The APIs go on to advise that:

The interviewer should ask the applicant to explain any delay in leaving and the RFRL [Reasons for Refusal Letter] should refer to and deal with the explanation given by the applicant.

Our study of Home Office Refusal letters in 2003 reveals that although this reason for refusal is used in many cases, there is rarely an indication that the applicant has been given the opportunity to explain his or her 'delay' in leaving.

\section{Ethiopia}

Refusal letter extract, June 2003

Further doubts as to your alleged fear of persecution can be drawn from the fact that you did not leave Ethiopia until May 1999 but that you were arrested five months earlier in January 1999. The Secretary of State holds the view that if your fear of persecution by Ethiopia's authorities were genuine you would have left Ethiopia at the earliest opportunity, and the fact that you did not detracts from the truthfulness of your claim to be a genuine asylum seeker

\section{Amnesty International comment}

It is very difficult to obtain travel documents and an exit permit in Ethiopia. A person fearing persecution and possibly under security surveillance would be at risk of human rights abuses if it was discovered that they planned to leave the country. Legal departure would not be possible because authorisation is required from the very officials responsible for the persecution. Illegal departure might then be the only option, despite the risk of being caught and the time such arrangements take.

The message to applicants that they did not leave their country soon enough is a confusing one. 'Delays' in departure - especially those that occur after numerous detentions - can be an indication 
that an applicant is seeking safety necessarily after having remained in his or her country for as long as possible.

\section{Iran}

\section{Refusal letter extract, June 2000}

You claim to have first been detained in 1979 for four months, you also claim to have been detained in 1981, 1983, 1993 and 1997. You claim to have been kept in solitary confinement and tortured when detained. The Secretary of State has doubts as to your alleged fear of persecution from the fact that you did not leave Iran until 1999. The Secretary of State holds the view that if your fear of persecution by the Iranian authorities was genuine, you would have left Iran at the earliest opportunity and the fact that you did not casts doubt on your credibility. (emphasis $\mathrm{Al)}$

\section{Amnesty International comment}

It is not explained why this applicant's fear of persecution by the Iranian authorities is negated by his date of departure from the country. This Refusal letter does not acknowledge the cumulative effect of persecution on the mind of an individual, nor does it recognise the enormity of the decision for the majority of asylum applicants to leave their country of origin without hope of return.

People who are committed to a cause in any country where there is a network of support for their activism, may maintain that degree of activism, until it becomes untenable or their life and safety are at risk. Amnesty International is aware of many such cases in Iran.

\section{Claiming asylum on arrival}

The credibility of asylum seekers who do not claim asylum at the point of arrival in the UK is also denied by the Home Office. The Home Office Asylum Policy Instructions to caseworkers define 'Factors affecting credibility'. These include:

The applicant failed, without reasonable explanation, to make an application for asylum at the earliest reasonable opportunity after their arrival in the United Kingdom, unless the application is founded on events that have taken place since their arrival in the United Kingdom.

It remains important, however, to consider the case as a whole, and particularly the circumstances surrounding the application and its timing. ${ }^{28}$

There is little evidence in Refusal letters that where asylum applicants make their claim after arrival in the UK, the 'case as a whole' is sufficiently considered by caseworkers. Asylum seekers may face many obstacles to claiming asylum on arrival. For example they may not understand asylum procedures. The small notices in different languages at the airports and ports are not adequate and, in the words of a High Court Judge, are 'neither numerous nor conspicuous - there are considerable limitations upon the extent to which reliance can be placed on them. ${ }^{29}$

Asylum seekers might not speak English and this inhibits them from trying to communicate with immigration officials. They may be ill or exhausted from harrowing journeys; they are afraid of being returned immediately to their country of origin. They may be acting on instructions from their agent, who may even be accompanying them. Those who have fled repressive regimes might be afraid of anyone who appears to be in authority. They may want to consult their families, friends and communities about what action to take.

The Home Office acknowledges some of these factors in the Asylum Policy Instructions, the expectation that asylum applicants should claim asylum on arrival is a strict one.

\section{Rwanda}

\section{Refusal letter extract, March 2003}

Although you arrived in the United Kingdom on the 7 August 2002, you did not claim asylum until 12 August 2002. Whilst the Secretary of State is aware of disorientation resulting from your journey and arrival in a country where you did not fully understand the language, he considers your delay in applying to be unreasonable. He considers this had undermined the credibility of your claim.

He must question why, if you felt to be in genuine fear of your life and wanted to seek international protection, why (sic) you would not have availed yourself or attempted to avail yourself of the protection of the United Kingdom by claiming asylum at the earliest opportunity at the arrival airport (sic), irrespective of any lack of specific knowledge of how to accomplish this. (emphasis AI)

\section{Amnesty International comment}

The expectation appears to be that this applicant would claim asylum on arrival at the airport without knowing anything at all about how to do so, or even that it was possible. This applicant claimed asylum five days after his arrival which should be considered reasonable in light of the fact that he did not understand English well and did not know about asylum procedures. His 'delay' in claiming asylum should not be linked to his need for international protection. 


\section{5.}

Talking of pain

\section{Applicants who allege torture': The Home Office's consideration of credibility and medical evidence}

During my detention and after, I had shut down my mind from the daily happenings because they were painful to me. I was locked up, I was a prisoner, I was whipped, raped, beaten done absolutely anything yet I could not escape from that. Somebody was in control of me, my sleep, when to sleep/wake up, my clothes, my bedding, my bed, how to urinate, excrete, stand up, sit down, food and when to eat, my body, my freedom, my actions etc, my mind blocked up and I survived it. The authorities who are supposed to protect me were treating me this way. They inflicted pain on me and took over my control and life. I did not deserve this treatment, I had not committed any crime.

- Extract from the asylum statement of a Kenyan man facing removal from the UK in 2004

\section{Credibility of torture allegations}

Torture involves the dehumanisation of the victim, the severing of all bonds of human sympathy between the torturer and the tortured. Torture is a crime against humanity. No state in the world admits to practising torture and yet Amnesty International received reports of torture or illtreatment in 150 countries between 1997 and 2000. ${ }^{2}$ Under s.134 of the Criminal Justice Act ${ }^{3}$ torture by a public official or person acting in an official capacity is a crime that can be prosecuted in the British courts regardless of the nationality of the perpetrator, or the country in which torture was alleged to have taken place. $^{4}$

The treatment of asylum applicants who allege that they are victims of torture is of great concern to Amnesty International. Refusal letters received by Amnesty International in 2003 reveal that consideration of torture allegations and medical evidence is inadequate at each stage of the initial decision-making process.

Torture is a complex subject, and one that has been extensively written about in the context of asylum claims by organisations such as the Medical Foundation for the Care of Victims of Torture (the Medical Foundation ${ }^{5}$ ) and other specialists in the field. ${ }^{6}$ However, because of its complexity and its stigmatising nature, torture is a subject about which little is known in wider UK society, and it is rarely scrutinised in public discussions and debates about asylum.

The Medical Foundation, the definitive specialist organisation in the UK which works with victims of torture and organised violence, estimates that it registers 6-9 per cent of the UK's asylum seekers as patients. However, this figure does not represent the number of asylum seekers in the UK who are victims of torture. The Medical Foundation has only limited capacity to work with a small percentage of those who are referred and torture survivors may not require treatment or may receive help from other services. In addition, it is often the case that the full details of torture are not disclosed by an asylum applicant and therefore a need for treatment and documentation may not come to light.

It is very difficult for many torture survivors to detail fully, or even partially, their experiences of torture, at the initial stage of their asylum claim. Full details of their background are more likely to emerge in a therapeutic relationship with a practitioner who can provide long-term counselling or treatment where it is required. Physical and psychological impediments may prevent torture survivors from giving an account of their experiences. The Medical Foundation says:

Some experiences of torture and ill-treatment are more likely to emerge later rather than sooner, even when no memory problems are present. Fear and distrust, humiliation and shame may make some experiences unmentionable. A torture survivor may fear that disclosure will put them or others at new risk of harm. They may think no-one will believe them. Or they may fear they will be blamed for what they have suffered.?

\section{The significance of torture to an asylum claim}

The experience of torture, in itself, does not guarantee a person entitlement to recognition under the 1951 UN Refugee Convention or to other forms of protection. ${ }^{8}$ For example it may be the case that the threat of torture no longer exists owing to a change in circumstances in the country of origin. It may also be the case that the torture suffered is not 
directly relevant to the reason for claiming asylum in the UK. Conversely, a person does not have to have suffered torture to have a well-founded fear of persecution or torture on return to their country of origin.

However, if an asylum applicant has experienced torture as a result of persecution for one of the reasons given in the 1951 UN Refugee Convention,' it may be important evidence - central to their asylum claim - that there is a 'reasonable degree of likelihood' 10 that they will face further persecution on return to their country of origin.

In addition, and in effect operating as a legal safeguard to those who do not fit the criteria enshrined in the 1951 UN Refugee Convention, Article 3 of the European Convention on the Protection of Human Rights and Fundamental Freedoms $(\mathrm{ECHR})^{11}$ creates an absolute prohibition on return to a country where there is a real risk ('serious possibility') that a person may be subjected to torture or to inhuman or degrading treatment or punishment. The act of removal of a person to such a country is in breach of UK law.

Amnesty International believes that it is essential that allegations of torture are fully investigated and fairly considered by the Home Office at the initial stage.

\section{The consideration of torture in Refusal letters}

From a study of Refusal letters submitted to Amnesty International in 2003, it is clear that torture allegations in relation to asylum claims are not afforded sufficient consideration. ${ }^{12}$ Refusal letters demonstrate serious misunderstandings about the characteristic and cultural responses of torture survivors and a misguided approach to the consideration of medical evidence. Refusal letters can 'under-report' the torture alleged in the summary of events of a case, for example referring to it as 'ill-treatment' or 'mistreatment' rather than 'torture', or only partially repeating the allegations made by an applicant. This contradicts the Home Office's own Asylum Policy Instructions to caseworkers which state that Refusal letters:

... should make it clear that all aspects of the application have been considered and should clearly identify all the reasons why the application was refused. ${ }^{13}$

Home Office Refusal letters ${ }^{14}$ indicate that caseworkers often consider torture in the context of their view of the 'credibility' of the asylum claim as a whole, without seeking to obtain, or allowing the applicant time to obtain, independent, corroborative medical evidence. Where the asylum claim is rejected in terms of the 1951 UN Refugee Convention, this is automatically mirrored in the consideration of
Article 3 ECHR, and usually explained in the briefest possible terms:

The Secretary of State has also considered whether the alleged treatment referred to in your claim might involve a breach of Article 3 of the Convention, but he does not consider that it would be breached in your case. ${ }^{15}$

This approach does not acknowledge the different criteria enshrined in the two very distinct legal instruments, both of which were intended to provide protection for victims of human rights violations. ${ }^{16}$

Amnesty International believes that the difficulties inherent in explaining experience of torture often, as intended by the perpetrator, leave the victim with feelings of anguish, embarrassment and fear about giving details of the experience. This should never disadvantage an applicant in the system of asylum determination. The Home Office should take steps to ensure that wherever there is a history of torture, it comes to light, and that evidence of torture in the form of testimony, objective country information and, where necessary, medical evidence, is considered seriously and with sensitivity.

\section{Home Office asylum interviews in relation to issues of torture}

The specific needs of applicants who are survivors of torture are often not met at asylum interviews. Currently Asylum Policy Instructions on torture are primarily contained in a section dedicated to the Medical Foundation for the Care of Victims of Torture. ${ }^{17}$ As of February 2004, the instructions give 'good practice' advice on interviewing alleged victims of torture but the advice is couched in negative and contradictory terms.

Interviewers must remain alert and receptive to the difficulties and barriers victims of torture may face in expressing highly traumatic experiences but they should not ask leading questions which may encourage applicants to fabricate unfounded claims of torture to support their application. In particular, they should not raise the subject if the applicant has not raised it. ${ }^{18}$

This overriding concern with false allegations of torture is misplaced. In fact, the Home Office's interviewing techniques result in the opposite situation: they do not find out the details of claims where torture is truthfully alleged. A recent study of Cameroonian applicants' cases by the Medical Foundation - all of whom had documented histories of torture - found that:

Interviewers generally failed to establish all of the following: the method of torture used; any equipment employed; the place where the torture took place; the duration of the ill-treatment; the frequency of abuse; the number of individuals involved in their torture; the immediate effects of the torture on the individual; the ongoing effects of torture, including the presence of 
scars, and the need for medical assistance, both immediately following the torture and any continuing treatment. ${ }^{19}$

The Home Office has been criticised for not training caseworkers to ask the right questions to present the applicant with an opportunity to disclose torture. For example, where a detention is mentioned, caseworkers may not ask important questions about the conditions in which they were held, how the applicant was treated, or, where torture is alleged and scars are shown, full details are not requested..$^{20}$

This approach can be detrimental to the applicant because significant issues that were given little attention in the interview can then arise in the Refusal letter, transforming a failing of the interviewer to one of the applicant.

\section{Nigeria}

Refusal letter extract, October 2002 The Secretary of State notes the marks on your body, however you have not provided any medical evidence to confirm how the marks had come to be there. Accordingly the Secretary of State does not consider that you have a well founded fear of persecution or that you would face treatment contrary to article 3 of the European Convention of Human Rights.

The hand-written record of the Home Office interview which relates to this applicant's injuries reads as follows:

Home Office Caseworker: Did the Voodoo priest pressure you to join?

Asylum Applicant: Yes. They did voodoo at me when I was in Lagos

Home Office Caseworker: What do you mean they did voodoo at me Asylum Applicant: You have to swear an oath and you have to shed blood for this oath and they mark you (applicant shows marks scratches (spelt: 'straches') around clavacle (sic) also marks on back and marks on my face. They are trying to frighten you so that if you run you think they are going to kill you.

Home Office Caseworker: Who told you about Christianity?

\section{Amnesty International comment}

This is an example of how opportunities can be missed at interview, where issues of torture or ill-treatment should have been pursued. The final question is entirely unrelated to what the applicant is saying about her experiences. Not only is this insensitive, but the introduction of an entirely different aspect of the asylum account would imply to the applicant that the discussion of her experience of torture or ill-treatment is now completed, or is not especially significant to her asylum claim. She would have no understanding from this exchange that it may be central - or that she should provide further medical documentation to substantiate it.

The issue of interviewing techniques has been raised on many occasions by the Medical Foundation for the Care of Victims of Torture with the Home Office and Ministers in and out of the public domain:

It does not make sense to ask 'Have you been detained?' or 'Have you been arrested?' but then not ask 'How were you treated?' Home Office interview records show that often the claimant says that s/he was tortured but the line of questioning too quickly turns elsewhere. ${ }^{21}$

Another area of concern about Home Office interviews is that, in cases where torture is alleged, the opportunity is seldom used to clarify apparent discrepancies which have arisen between the initial Statement of Evidence (SEF) form or statement and the responses to the questions at the asylum interview. This gives the impression that the aim of the interview is to discredit the asylum claim, rather than to establish the facts and achieve a detailed understanding of the case.

The failure to clarify discrepancies at the asylum interview contradicts the Home Office's own Asylum Policy Instructions to caseworkers, which warn:

The challenge to credibility will be weak unless the discrepancies are specified in the letter and unless the applicant has been given an opportunity to explain the discrepancies ${ }^{22}$

\section{Cameroon}

Refusal letter extract, January 2003 The Secretary of State notes that when you were asked at your asylum interview how you were treated during your two-day detention, you claimed 'we were not given any food or water... I was not brutalised in the cell...' However, the Secretary of State notes that in your SEF you claim '/ was severely brutalised' and in your Additional Statement, you stated 'Most of us were severely brutalised.' The Secretary of State considers that if you had really suffered this treatment as you allege, you would have stated it clearly at interview, rather than giving ambiguous answers in your various statements. (emphasis Al)

\section{Amnesty International comment}

It is evident that at two points in this applicant's written submissions, he has claimed that he was 'severely 
brutalised' in detention in Cameroon. The apparent discrepancy which has arisen in the interview - a statement that the applicant was not brutalised in the cell - could be due to:

- A misinterpretation or mis-recording of the verbal sentence, changing it from positive to negative. Mistakes of this kind can often happen in interviews which rely on interpreters and which are recorded in writing, rather than taped or videorecorded.

- A statement implying that 'brutalisation' took place outside the cell, for example in an interrogation room.

Of course, speculation does not clarify the details of the case. What is clear is that the interviewer should have clarified this apparent discrepancy at the interview, permitting the applicant the chance to explain further before refusing a claim from a country which is known to practise widespread and systematic torture of detainees.

\section{WORTH INVESTIGATING?}

Methods of torture known to be practised in Cameroon include 'balancoire' (suspension); 'bastinade' - beating on the soles of the feet; beating with truncheons, the flat of a machete, sticks, whips or lengths of tyre tread; electrical torture; cigarette and other burns; and being forced to crawl or walk barefoot over sharp objects. ${ }^{23}$

\section{Obtaining treatment in the UK}

It is clear that many survivors of torture will benefit from the help of professionals who are experienced in the field and understand the issues involved. However, asylum seekers can face obstacles obtaining treatment of any kind in the UK. Although they are entitled to treatment under the National Health Service (NHS), ${ }^{24}$ asylum seekers are sometimes forced to seek help in hospital casualty departments for routine health problems. ${ }^{25}$

Another obstacle to obtaining access to medical services (especially for asylum applicants outside London), is the language barrier for those who do not speak English. In addition, the policy of dispersing asylum seekers to different regions of the UK means that many are unable to access holistic specialist services for asylum seekers such as those offered by the Medical Foundation in London.

It is also the case that asylum seekers who have suffered torture are detained. Although asylum seekers are expected to be released from detention if a background of torture emerges, ${ }^{26}$ sufficient mechanisms are not in place to ensure that all applicants who have suffered torture are released and many remain in detention. ${ }^{27}$ Detained torture survivors suffer serious psychological effects which may compound damage done by previous detentions ${ }^{28}$, as well as restricted access to appropriate medical care. ${ }^{29}$

Asylum applicants with poor legal representation, may not have had the chance to relate their experiences of torture at all and may be unaware that specialist organisations, such as the Medical Foundation exist. Solicitors can be the 'gateway' for applicants to access medical treatment, or psychological or psychiatric services. However, their time, willingness and resources to engage in this vary widely.

Despite these obstacles, Refusal letters contain denials that torture has occurred, based upon the applicant's failure to seek or obtain treatment in the UK.

\section{Cameroon}

\section{Refusal letter extract, April 2003}

You claim during the time you were in detention you were ill-treated and forced to watch your father being beaten after he stopped the officers having sex with you.

You claim you have suffered from nightmares since your arrival in the United Kingdom and that your experiences have left you 'very traumatised and nervous'. But you have sought no help to improve your mental health following your experiences in the Cameroon. Given this claim and that you were sent to the United Kingdom to find a place of safety, the Secretary of State would have expected you to seek medical help, or have been offered such help for this serious problem on your arrival (emphasis Al)

\section{Amnesty International comment}

This letter is addressed to a 15-year-old girl. It appears that the allegation of 'ill-treatment' (which constitutes torture) in detention is not believed because the applicant did not obtain medical treatment in the UK. In addition, the applicant's credibility appears to be doubted because she was not offered treatment on her arrival in the UK. This applicant claims that she is traumatised by her experiences, giving rise to psychological problems including nightmares. How this would be immediately obvious to medically unqualified immigration officers at the airport is not clear.

Aside from overlooking the applicant's age when considering her account, the Home Office has failed to consider whether seeking medical help for a psychological complaint would be culturally appropriate. The asylum statement reads:

They asked my father many questions and they beat him in front of us as well. They used a long black stick to beat him. I do not know how many times they did this in front of us, but it was more than once. Sometimes they would just pull him 
out of the room and beat him. When he came back he would have a swollen eye, a swollen mouth and injuries on his shoulders. They did not ask the questions in front of us. They did not ask me or my siblings any questions.

Whilst at the police station, some of the male police officers undressed me. They wanted to have sex with me and my father said no and they beat my father up. They did not have sex with me or beat me - I see this scene at night now all the time.

A sensitive analysis of this account would include consideration of the account in full and the commissioning of corroborative medical evidence if questions of credibility arose. The age and capabilities of the applicant would be borne in mind throughout consideration of the case. The account of 'attempted' rape should not be assumed to mean that rape did not actually take place - it may be that the applicant is too afraid to admit that full rape was carried out. ${ }^{30}$

It would be noted that there are no obvious features of exaggeration in the applicant's account. If anything, the applicant's statement is understated, using the term 'have sex' instead of 'rape'. The Home Office should understand and use the appropriate terms for 'attempted rape' in the Refusal letter.

\section{Allegations of torture considered in the context of general 'credibility' of the asylum applicant}

Refusal letters are often couched in terms of incredulity about torture allegations which gives an overall impression that the Home Office views many of them as a fabrication. This contradicts Amnesty International's documented information about torture practised worldwide and the long-term experience of torture specialists and medical practitioners:

If one were to fabricate an abusive allegation of torture one would need to fabricate injuries (which are not self inflicted) and/or a mental state consistent with having been tortured. We do not say this is impossible but it is far more difficult and more susceptible to detection than other assertions. ${ }^{31}$

Torture is regularly dismissed in Refusal letters on the basis that the applicant's overall account is considered to be 'not credible' and that means that the account of torture is 'not credible'. Amnesty International believes that allegations of any kind of torture are serious enough to warrant independent consideration, regardless of the Home Office's opinion of the 'credibility' of an applicant's claim as a whole. This is especially important when the Home Office's country information and assessments of the credibility of applicants are not of a high enough standard to be safe.

\section{Democratic Republic of Congo}

Refusal letter extract, January 2003

For reasons of credibility set out above the Secretary of State does not believe you were ever actually detained by rebel forces in the Democratic Republic of Congo. Subsequently he does not believe that you have suffered beatings and had an electrical current passed through your testicles as claimed...

\section{Amnesty International comment}

Because the Home Office does not believe the account as a whole, it has chosen not to investigate the allegations of torture at all. Yet the allegation is serious, and one which should warrant investigation, especially considering that electrical current administered this way is a known method of torture in DRC.

The consideration of torture allegations in the context of general credibility leads to inappropriate 'clinical' judgements being made by the Home Office, without reference to independent medical advice.

\section{Russia (Chechen)}

Refusal letter extract, January 2002 The Secretary of State notes from your asylum interview that you claimed to have severe internal injuries and when discovered in hiding by the Russian Special Services you were beaten unconscious. However you stated that you managed to escape from the Russian Special Services and run 500 metres to a disused mill where you hid for 24 hours. You also claimed that after an operation you escaped from the hospital by jumping through a window even though you were still connected to a blood drip. The Secretary of State is of the opinion that a person as injured and ill as you claimed to be would not be able to achieve the physical feats that you have claimed. He considers that this casts doubt on the credibility of your claim.

\section{Amnesty International comment}

It is unreasonable for the Home Office to assert that an individual in desperate circumstances could not achieve certain physical feats without reference to medical information about whether such feats were possible. In this case, the Home Office should perhaps be asking why, if the account of escape is not true, it is so detailed? What would be the benefit to the applicant of claiming an improbable feat of escape? 


\section{No scars or injuries}

The fact that many countries use methods of torture that do not result in external physical scarring or injury is documented in medical reports, international journals and articles. ${ }^{32}$ Many countries are concerned about their international reputation and their agents use methods which cause 'invisible' scars, such as the chiffon method of choking detainees with cloth in Algeria; the practice of walking applicants around on their feet immediately after falaka (feet beating) in Iran and Turkey, to reduce swelling and injury; and the use of plastic pipes filled with sand and gravel or concrete in Sri Lanka which, when used to beat a victim, spreads the force of the blow so that the skin is not broken but the pain is intense. In some countries torturers wrap batons in cloth before beating victims, to avoid rough edges which can leave scars. ${ }^{33}$ The Medical Foundation says that:

Often a significant amount of time has elapsed since the torture or violence. In some instances, torturers leave gross scarring, fractures and paralyses. In others, techniques are used which cause only transient bruising or physical sequelae. The absence of any physical or psychological signs is not proof that torture has not taken place. ${ }^{34}$

Although this is widely documented, Home Office decision-makers do not appear either to acknowledge or to understand it.

\section{Democratic Republic of Congo}

\section{Refusal letter extract, October 2003}

You claim that you were beaten with whips, thrown on the floor and suffered head injuries and yet you state that you have no external scaring (sic). It is believed that if you were beaten so badly you would have had extensive scaring...(sic)

\section{Amnesty International comment}

This allegation of torture was dismissed on the basis of a clinical judgement made by a medically unqualified caseworker about the lack of scarring of the applicant. Without a medical report it is not possible that the caseworker would have a detailed knowledge of the applicant's scars. S/he certainly would not have knowledge of the clinical likelihood of 'extensive scarring' in this context. It would not be possible to make judgements about scarring without finding out details about, for example, whether or not the applicant was beaten through her clothes, whether her skin was broken at any point, and if so whether the wounds were full skin thickness or not, and whether the time that has elapsed would cause scars to fade. Scars which are not of full skin thickness heal relatively quickly and may leave no permanent mark. Skin colour pigmentation means that some skin shows scars or marks for longer. Beating with whips might cause light linear scars that would fade quite quickly.

Amnesty International believes that where there is doubt, a medical report should be requested and the decision should be delayed until it has been received and considered. Alternatively, the Home Office should commission independent medical evidence itself before arriving at clinically based conclusions about scarring or other injuries.

Of course, some effects of torture are 'invisible' because they are psychological.

\section{Democratic Republic of Congo}

\section{Refusal letter extract, May 2002}

You have also stated that during your alleged three month detention, you were not beaten or physically tortured, but were 'morally tortured' as you had to watch others being beaten. The Secretary of State does not consider this to amount to persecution -

\section{Amnesty International comment}

Article 1 of the UN Convention Against Torture ${ }^{35}$ states that torture constitutes physical or mental suffering. This applicant submitted the following account at her appeal hearing:

[first detention] We were taken to Camp [name] and detained there. While we were there we were beaten and mistreated. We were also forced to watch Rwandans being beaten. I believe some of them died as a consequence of this. We were kept in a cell together for around three months.

[second detention] That night they again threatened me by taking me to what was known as the shooting room. This was a room where people were killed. I could see blood on the floor and on the walls, and there were bodies lying there. They told me that I must tell them the truth about [name] and if I did not, I would end up in this room as others had done. I was terrified. I was taken to this room about three times a night. This happened every night except for two nights when I was taken to the Zaire river. What happened was that at about 1 in the morning, I was taken outside and put in a lorry with other prisoners and with soldiers. I thought that I was going to be released. Instead, we were taken to the river and they told me that they would throw me in if I would not admit to what they wanted.' (emphasis Al)

The emphasised parts of this statement are all examples of torture and the experience as a whole would constitute torture. There is no indication in this Refusal letter that this applicant's claim to have suffered torture has been fully or adequately considered.

When describing their experiences, many people say that watching others being tortured is the 
most distressing. - The memory of seeing someone screaming for help, yet being unable to do anything, lingers for many years. These memories return as nightmares, or they come when a person is trying to concentrate on something else. They can be very disruptive to normal social functioning, but there is no objective way of showing that they exist. ${ }^{36}$

\section{Late disclosure of torture: rape and sexual violence}

Torture and other persecutory treatment can produce a profound shame response. Humiliation and shame are often the desired goals of the perpetrator. This shame response may be a major obstacle to disclosure.

Experience has shown, for example, that incidents of sexual abuse may not come to light for months or even years $^{37}$

'Late disclosure' of any form of torture is understandable, yet it is regularly used by the Home Office to justify dismissing an asylum claim altogether. 'Late disclosure' usually refers to the fact that the asylum applicant did not mention that he or she had been tortured at the very first stages of the asylum claim.

The problem of late disclosure is particularly prevalent with asylum applicants who have been raped. Rape can be suffered by both men and women. There are many reasons why rape and/or sexual violence may not be disclosed by an applicant. At the basic level, there may be problems obtaining adequate legal representation or explaining events in the short time permitted to prepare the initial 'SEF' application. There can also be problems related to the asylum interview, in which questions about treatment in the country of origin, even in cases where detentions are alleged, are not fully explored or are explored in an inappropriate environment.

The Immigration Appellate Authority Gender Guidelines acknowledge that information regarding rape can often be initially put forward by the applicant in a partial form. This could be due to a fear of dealing with the enormity of the incident as a whole, or for cultural reasons:

Special care must be taken in relation to evidence pertaining to sexual violence; care must be taken before drawing any adverse inferences where an appellant, or other witness, has earlier described a rape as an attempted rape or as touching, beating or other ill-treatment or even as pain or illness. ${ }^{38}$

\section{Women who allege rape}

With regard to women who have been raped, the UN Special Rapporteur on Torture states: ${ }^{39}$ In addition to being an especially traumatic form of torture for the victim, rape may have insidious correlative consequences. In many situations a woman may be reluctant to seek redress by reporting rape because of the severe social repercussions that may flow therefrom. The stigma attached in many communities to a woman who has been raped may result in particularly dire consequences for the private and public life of the woman. In addition to social stigma, some victims may be subjected to direct reprisals from relatives. In a few countries where severe legal sanctions have been adopted against adultery and where the evidentiary requirements to demonstrate rape are stringent, a woman reporting a rape may risk holding herself open to prosecution.

This clearly makes the point that women from certain cultures, in stating that they have been raped, will feel that they are admitting something bad about themselves, rather than about the perpetrator. Many come from countries where the shame surrounding rape is such that perpetrators know they can be assured of their victim's silence. Any person who has interviewed asylum claimants about rape, will know that it can be helpful to explain the differences in cultural viewpoints between the UK and the applicant's own country, to enable them to feel more comfortable about detailing their experiences. This stigma arises in addition to the general problems that any person would have in telling a stranger or an official in a foreign land about being raped.

\section{Iran}

\section{Refusal letter extract, May 2001}

When describing your mistreatment in prison you refer to being subjected to activities of a tortuous nature (sic) such as food deprivation, suspending upside down and daily beatings, yet you claim that you were able to prevent your captors sexually abusing you by denying them, although 'they tried to'. The Secretary of State is aware of the harsh conditions that exist in Iranian detention centres and rape is known to have been inflicted on inmates. He cannot accept that rape and sexual abuse are regarded as a matter of the inmate's choice in the manner that you have claimed and must therefore conclude that you have, at best, exaggerated your account.

\section{Amnesty International comment}

This Refusal letter 'under-reports' the torture alleged, describing it as 'mistreatment'. It acknowledges the 'harsh conditions' and practice of rape in detention in Iran, but denies the credibility of the applicant on the basis that she has presented rape as a 'choice' because she has described it as being attempted. It is well 
documented that many women find the full details of rape too stigmatising to disclose.

Threat of rape in a society like Iran, with its particular stigmatisation of rape victims, would be sufficient to cause mental anguish of a severity amounting to torture. However, the allegations of torture in this account are worthy of investigation whether or not the applicant was raped or threatened with rape.

\section{Men who allege rape}

Of course, just as rape is culturally stigmatising for women, its effects are also devastating for men. The UK Metropolitan Police guidelines on victims of male rape state that:

There is much myth around the sexual assault of men, which leads to many misunderstandings about the crime and the victims it affects. This has consequences in the way that men see themselves as victims of sexual crimes and stops them from talking about what has happened to them and getting help.

The advice of the Metropolitan Police to those to whom rape is eventually disclosed is: Respect the courage it has taken him to tell you - listen, believe, support. ${ }^{40}$

These guidelines apply to men who have suffered rape in the UK. It is difficult to imagine the impact on the psyche of a person who comes from a country where rape, the rights of sex abuse victims and homosexuality are never openly discussed and are taboo or illegal. However, immediate disclosure from male applicants is still expected by the Home Office.

\section{Algeria}

\section{Refusal letter extract, March 2003}

The Secretary of State notes that during interview you failed to mention rape. The Secretary of State also believes that it would be reasonable to expect that you would have mentioned this at the earliest opportunity. Furthermore the Secretary of State concludes that the fact that you did not undermines the veracity of your claim.

\section{Amnesty International comment}

Amnesty International believes that late disclosure of rape should never be considered to 'undermine the veracity' of an entire asylum claim - whether or not the allegation of rape itself is believed by the Home Office. This is because rape is very difficult to prove and to document medically and therefore doubts about its occurrence should not be central to the decision on an asylum claim. ${ }^{41}$

In this particular case, it appears that rape was in fact disclosed after the asylum interview, and prior to the decision being made. This is early on in the process, considering the sensitivity of this issue for the applicant.

\section{WORTH INVESTIGATING?}

Male rape is known to have been practised in Algeria. It is a taboo subject there, as it is in various other countries in North Africa and the Middle East. In practice, the shame associated with male rape means that very few individuals would feel able to talk about it openly afterwards.

\section{Definitions of torture and 'persecution' in Refusal letters}

Home Office caseworkers are not sufficiently trained in legal definitions of torture and the significance of allegations of torture to a claim for international protection.

The Home Office is known to assert that torture is motivated by reasons other than those of the 1951 UN Refugee Convention without providing adequate reasons.

\section{Chad}

\section{Refusal letter extract, April 2001}

Whilst in detention you claimed you were beaten, tortured and questioned about your attempts to find your father's killers.

The Secretary of State believes that the treatment that you allege to have received resulted from your attempts to find your father's killers. You stated that you approached a bodyguard of the president and asked for his assistance in tracing the people responsible; this, in turn, led to your arrest when it became known that you were trying find (sic) the assassins. The Secretary of State therefore considers your arrest and physical mistreatment whilst in detention, to be a result of those enquiries rather than because of your own political opinion.

\section{Amnesty International comment}

This Refusal letter does not negate the background of torture, but the motivation behind the torture. The Home Office has failed to explain why detention and torture as a consequence of the applicant's enquiries about his father's killers do not constitute persecution for a reason under the 1951 UN Refugee Convention.

With regard to Article 3 of the European Convention for the Protection of Human Rights and Fundamental Freedoms $(E C H R)^{42}$ the prohibition on removal to a country where a person will face a real risk ('serious possibility') of torture and/or inhuman or degrading treatment or punishment is absolute and applies to every person, regardless of the reason behind it. Nonetheless, in this Refusal letter, the claim for protection under Article 3 of the ECHR is dismissed 
without adequate consideration:

You have claimed that you will be tortured if you are returned to Chad, but for the reasons outlined above, the Secretary of State does not consider that there are substantial grounds for believing that there is a real risk that you would face treatment contrary to Article 3.

\section{Turkey}

\section{Refusal letter extract, February 2003}

The Secretary of State has taken account of the numerous reports from human rights organisations such as Amnesty International, about the situation in Turkey. They have reported the systematic use of torture by the Security forces, deaths in police custody, disappearances and so-called extra-judicial executions. The Secretary of State understands that the reports (sic) of torture are normally individuals who have been involved or suspected of involvement in criminal or illegal separatist/terrorist activities. The Secretary of State has considered your application against this background and would not seek to return you to Turkey if he were satisfied that you were of adverse interest to the Turkish authorities for reasons of race, religion, nationality, membership of a particular social group or political opinion. (emphasis Al)

\section{Amnesty International comment}

It is unacceptable to torture any suspect. Torture is a disproportionate punishment in any situation and the return to a country where an applicant may face torture is absolutely prohibited under Article 3 of the ECHR. However, it is possible that a person in Turkey who is suspected of being involved in 'illegal separatist/terrorist activities' may be wrongly suspected and wrongly imprisoned - making their detention one that could relate directly to their being persecuted for one of the five reasons in the 1951 UN Refugee Convention. The Home Office's own Asylum Policy Instructions state:

Prosecution could be considered persecution if it involves victimisation in its application by the authorities, eg if only certain ethnic groups are prosecuted for a particular offence, and the consequences are sufficiently severe. Punishment which is cruel, inhuman or degrading (including punishment which is out of all proportion to the offence committed) may also constitute persecution. ${ }^{43}$

Amnesty International is aware that reports of grave human rights violations in Turkey persist at the current time. Too often the issue of 'national security' has been invoked and emphasised by the authorities at the expense of human rights. The criminalisation of nonviolent expression that is critical of the Turkish state is enshrined in Article 159 of the Turkish Penal Code, which, in its amended form, criminalises statements deemed to be made with the 'intention' to 'insult or deride Turkishness, the Republic, the Grand National Assembly or the moral personage of the government or the State's armed forces or security services or the moral personage of the judiciary'. Freedom of expression in relation to 'national security' is also criminalised under Article 312/2 ('incitement to enmity based on class, race, religion, sect or regional difference'), Article 169 ('aiding and abetting an illegal organisation) and Article 7 ('propaganda for an illegal organisation') of the Anti-Terror Law.

During 2003 Amnesty International received regular reports of detainees - including those who were not charged with national security offences - being beaten, stripped naked, sexually harassed, subjected to repeated verbal intimidation including death threats sometimes accompanied by mock executions, and being subjected to restriction on sleep, food, drink and use of the toilet.

\section{Medical evidence \\ When is medical evidence necessary?}

It appears from a study of Refusal letters submitted to Amnesty International in 2003 that the Home Office often requires medical documentation as evidence of experience of torture. However, at no point prior to the asylum interview is this formally communicated as a requirement to the asylum applicant. It seems to be rarely requested at the asylum interview either, despite Home Office Asylum Policy Instructions that might suggest otherwise. ${ }^{44}$

In the opinion of the Medical Foundation for the Care of Victims of Torture, a report is required only in complex cases, where there is a need for medical analysis of the injuries to determine whether and to what extent they are consistent with their stated cause:

The Medical Foundation notes an increasing requirement to provide medical evidence in any and all cases where torture is alleged thereby raising the burden and standard of proof in asylum cases. Very often the scars themselves corroborate testimony and do not require further corroborative medical evidence or explanation. ${ }^{45}$

'Psychological scarring' is viewed differently: It can be helpful to describe the process whereby testimony of torture has been obtained during the course of a therapeutic relationship. Evidence (taken over time) of the therapeutic relationship may provide some corroboration of evidence obtained elsewhere, including testimony given to legal representatives and the Home Office. ${ }^{46}$

However, just as there are obstacles to obtaining 
treatment for torture survivors, there are also obstacles to obtaining medical evidence. In the case of asylum claims which have been subjected to fast track procedures, there is a very real fear that a person may be removed from the UK before a medical report has been obtained which corroborates their account of torture. ${ }^{47}$ For asylum claimants who are processed under regular asylum procedures, it is difficult to obtain medical evidence in time for the submission of the initial SEF or the substantive asylum interview, after which time it is rare that further submissions will be accepted. There is a concession for postponement of a decision to permit time for the receipt of Medical Foundation reports, ${ }^{48}$ but this does not apply to reports by any other medical practitioners and the concession therefore gives an advantage only to those torture survivors who can guarantee documentation from the Medical Foundation. The Medical Foundation is not the only reputable source of medico-legal reports and it considers that the Home Office concession should be extended to any bona fide expert.

Any medical practitioner who is asked to provide a report will need to interview and examine the asylum applicant. This often has to be done through an interpreter and usually within a limited time. The experience can be particularly harrowing for some survivors of torture, who may have difficulties explaining sensitive details of their history or injuries and conditions to the practitioner, removing their clothes in front of strangers or submitting to a sensitive medical examination. It is also difficult in many cases for psychiatrists or psychologists to obtain detailed information about an applicant without having the time and opportunity to build the necessary relationship of trust and offer reassurance. Torture survivors respond to their experiences in different ways but it is true to say that many will relate the experience of being questioned or examined to previous traumatic or invasive incidents in their history.

Obtaining a medical report which is appropriate for the purposes of consideration of an asylum claim may be more difficult for asylum applicants who have been 'dispersed' outside London. ${ }^{49}$

Whatever the circumstances of the individual case, the fact is that the only asylum applicants who will obtain substantive medical evidence of any kind, at any stage in the process, are those whose legal representatives commission it for them. It is simply not possible for the vast majority of asylum applicants to commission a medical report for themselves. They would be unable to instruct a medical practitioner on what was required for the purposes of consideration of their claim and the cost would be prohibitive in most cases. ${ }^{50}$

The waiting list for a report from the Medical Foundation commissioned by a solicitor is approximately eight weeks. However the Medical Foundation has found that the majority of reports are commissioned 'late', after a refusal has been issued on the case. Only a minority of solicitors are knowledgeable about the importance of 'frontloading' cases from the beginning by referring torture survivors to the Medical Foundation or other specialists promptly. However, solicitors may also be concerned that the Home Office will consider the medical evidence inadequately and that they will then be unable to use the medical report to advance the case at appeal. Even a solicitor who commissions a report immediately after taking instructions from an asylum applicant will find themselves racing against the clock. It is possible that the full asylum interview will have taken place by the time the medical evidence is obtained. Applicants who have suffered torture can be disadvantaged by the inability to present corroborative evidence at the time of their asylum interview. ${ }^{51}$

The new 'maximum disbursement limits' on provision of legal aid will seriously curtail the possibility of providing medical evidence. From April 2004 funding for medical reports beyond the restrictive maximum limit will rely on the opinion of an officer at the Legal Services Commission who will not be acquainted with the applicant concerned, and is unlikely to possess an informed understanding of medical issues. ${ }^{52}$

Amnesty International has seen examples of asylum cases that have progressed to the end of the asylum process without a medical report being commissioned by their legal representative at any time..$^{53}$

\section{The difficulties inherent in the medical documentation of torture}

Even in cases where medical documentation can be obtained and submitted within the very strict time limits on asylum cases, there is the additional problem that medical specialists can only document injuries, illnesses and conditions. It is rarely possible for a physician or psychiatrist to make a conclusive link between the symptoms and their cause. The Medical Foundation takes the following position:

Medical evidence does not have to prove torture. Indeed, with few exceptions, it can only correlate injury to testimony. If, however, medical evidence establishes that the physical and/or psychological signs are consistent with the applicant's specific history of torture, the required standard of proof has, ipso facto and ipso jure [in law and in fact] been met. ${ }^{54}$ (emphasis $\mathrm{Al})$

Unfortunately, this advice is unheeded by the Home Office. Misunderstanding of the non-conclusive nature of most torture documentation is evident in its Asylum Policy Instructions to caseworkers: 
An applicant's poor credibility can also affect the weight put on scars and although the Medical Foundation may consider the evidence to be consistent with the applicant's claims to have been tortured caseworkers should note that this is non-conclusive. ${ }^{55}$

This advice must be confusing to caseworkers. Without medical knowledge or appropriate definition of 'credibility' as it is meant here, they are supposed to make an essentially clinical judgement about the cause of the scars of an asylum applicant. Although the Home Office acknowledges the Medical Foundation as a 'bona fide' torture specialist organisation, ${ }^{56}$ caseworkers are given licence to reject its evidence as 'non-conclusive' when it must be by definition 'non-conclusive' in most cases.

\section{Kuwait}

\section{Refusal letter extract, May 2003}

The Secretary of State is aware that your situation is sensitive but believes that the reports do not conclusively point out that your mental state was produced only by alleged imprisonment and torture you suffered. (emphasis AI)

\section{Amnesty International comment}

There appears to be a tacit acceptance by the Home Office that the applicant's mental state is at least partially due to imprisonment and torture, which would indicate that his account of having been detained and tortured is truthful.

\section{Rwanda}

Refusal letter extract, February 2003 The Secretary of the State (sic) is aware that you have provided a psychiatric report and the Secretary of the state (sic) accepts that you have some type of depression but the Secretary of the State (sic) believes that this depression is not due to the asylum claim.

\section{Amnesty International comment}

It is not explained how the Secretary of State is qualified to decide the cause of this applicant's depression or what the significance of his finding is in the context of the asylum claim. Also, no detail is provided about how the conclusion has been reached.

\section{Where no medical report is submitted in support of the asylum claim at the initial decision stage}

It appears that where no medical evidence is submitted to support an asylum claim at the initial decision-making stage, the Home Office can dismiss an applicant's claimed experience of torture without any further investigation of the allegations. This is despite the knowledge that many asylum applicants will have been unable to obtain a medical report - or will not even know that a report is required.

\section{Sudan}

\section{Refusal letter extract, May 2002}

Although you claimed to have been physically beaten in detention, the Secretary of State observed that you have yet to provide any evidence of the ill treatment you allegedly received.

\section{Amnesty International comment}

It is clear that this applicant's account of his experiences of torture consisted of far more than 'beating in detention'. His asylum statement, which was submitted prior to his asylum interview, detailed torture including: being beaten by a wooden bar all over his body, causing him to vomit blood and suffering a stomach ulcer; being put in a wooden box and having the soles of his feet flogged, causing a broken toe and problems with his genitals; being denied food and drink; having burning wood placed on his leg causing a burn scar and being punched and hit with wooden bars.

The under-recording of this applicant's allegation of torture in the Refusal letter means that it cannot have been properly considered. This applicant later had the details of his injuries sustained under torture documented by the Medical Foundation.

\section{WORTH INVESTIGATING?}

There have been a number of testimonies of torture Amnesty International has received from Sudan. The likelihood of suffering torture or other ill-treatment is especially high in Darfur, Western Sudan, where this applicant was arrested.

Methods of torture in Sudan known to Amnesty International include: beating all over the body with sticks, hands, or hoses; kicking; having cold water poured over one and being beaten or being held next to a fan; burnt with cigarettes; rape (for women); objects pushed up the anus; use of electric shocks; pouring on battery acid; being kept in contorted positions; being forced to take physical exercise (the 'rabbit jump') or stand with hands up; pressure on the body or genitals; suspension from the ceiling; being forced to stand or sleep in water and deprivation of sleep. 


\section{Where a medical report is submitted in support of an asylum application at the initial stage}

It appears from a study of Refusal letters that medical reports from the Medical Foundation for the Care of Victims of Torture are the preferred source of documentary evidence for the Home Office on cases in which torture is alleged. The Home Office has dedicated a chapter of Asylum Policy Instructions to the Medical Foundation which include a special concession to delay a decision for Medical Foundation evidence that is guaranteed to be submitted after the asylum interview. ${ }^{57}$ However, the Medical Foundation is an independent registered charity and, although it engages in discussions with the IND about issues relating to its client group, it is not funded by the Home Office and remains independently critical of the Home Office's decision making on asylum claims. ${ }^{58}$

The 'endorsement' of the Medical Foundation by the Home Office is significant, because it indicates over-reliance on a specialist organisation that does not have the resources to respond to, treat or report on every asylum application where torture is alleged. The Medical Foundation believes that the apparent reliance on its authority can be misleading when its information on torture and applicants who allege torture is used selectively by the Home Office, or Medical Foundation medical reports are disparaged in Refusal letters. The Medical Foundation believes that where corroborative medical evidence is required, the Home Office should commission its own independent medico-legal reports, but chooses not to.

Reports which are not produced by the Medical Foundation are often dismissed in Refusal letters. In several Refusal letters received by Amnesty International in 2003, the author of a medical report is stated to be unqualified to document torture injuries and symptoms - without any reference to the qualifications or criteria by which this judgement has been made. This contradicts the view of the Medical Foundation, which disapproves of the practice of the Home Office in disregarding medical reports produced by other practitioners or agencies on the grounds, chiefly, that they are not from the Medical Foundation. Despite the practical problems of documenting torture experienced by asylum seekers (language barriers, time constraints and access of practitioners to experienced torture specialists) General Practitioners have training and experience in many, if not all, the medical areas required for such reports. Dr Paul Williams, a GP who runs the 'Arrival' NHS practice in Stockton-onTees for asylum seekers, ${ }^{59}$ states that:

Those GPs who take advantage of the on-going training offered by the Medical Foundation to medical practitioners across the UK, will benefit greatly in their increased understanding of the documentation of torture. However, there are many G.Ps in the UK who regularly see asylum seekers as patients in their surgeries, and have the experience and knowledge of the cultural context relating to allegations of torture as well as the medical qualifications and skills to produce impartial and accurate medical reports. G.Ps are regularly asked to provide reports for different legal purposes, such as determination of the right to claim incapacity benefit, insurance issues and for criminal court cases. Many therefore have experience of producing medical evidence to court standard and understand what is required.

\section{Croatia}

Refusal letter extract, January 2002 The Secretary of state has noted the opinion expressed by [name] Women's Centre [regarding your alleged rape], but has decided not to attach any weight to it because the qualifications and experience of the author of the report has not been disclosed.

\section{Amnesty International comment}

If the qualifications and experience of the author of a report are an issue for the Home Office, this should be because they are insufficient, not because they are not written on the report. The omission is one made by the author and not the applicant, and therefore the author's $\mathrm{CV}$ should be requested before a decision made.

An investigative approach to this claim might take the view that information from an established women's centre may be useful, considering the difficulties inherent in physically documenting rape. ${ }^{60}$ They may have had considerable experience with women who have been raped and would probably be unwilling to support a case that they did not find credible.

\section{Pakistan}

\section{Refusal letter extract, June 2003}

The Secretary of State has considered the medical report submitted in support of your claim. However, the Secretary of State is of the opinion that the report does not add any substantial weight to your claim

\section{Amnesty International comment}

There is no explanation as to why the report does not 'add any substantial weight' to this applicant's claim. Amnesty International believes that if that is the case, a full explanation of why the report is dismissed should be clearly recorded. 


\section{Medical evidence considered in the context of general 'credibility'}

Medical reports which detail the claimed background of asylum applicants can be doubted in Refusal letters on the basis that their author is merely taking at face value the account of the individual and therefore the report is not worthy of further consideration. This is a serious error. The Istanbul Protocol, which was produced in 1999 by more than 75 experts in law, health and human rights, and sets out minimum standards for the documentation of torture, has detailed instructions on obtaining testimony, and states that:

Witness and survivor testimony are necessary

components in the documentation of torture. ${ }^{61}$

Dr Paul Williams of the 'Arrival' NHS practice for asylum seekers in Stockton-on-Tees states that:

The most important tool of a medical practitioner is his or her consulting skills. Documenting injuries without testimony, is of little use in determining their likely cause. General Practitioners have the necessary medical skills to judge whether injuries or symptoms are consistent with testimony - and training which acknowledges that $90 \%$ of diagnosis comes from the history of the patient. If you are looking at a scar, for example, you will ask the patient how it occurred, what appearance it had initially and how it changed over time. You will note throughout the consultation the overall picture of behaviour of the patient and their responses when they are asked to provide further detail about their account. Observations of the physical scar itself in relation to testimony, the emotional response of the patient and the ability (or not) to elaborate upon the incidents that gave rise to its appearance, all contribute to the findings of the practitioner, whose job it is to state if they find the injuries inconsistent.

\section{Colombia}

\section{Refusal letter extract, March 2003}

The Secretary of State has carefully considered the medical report you have submitted in support of your application, relating to your mental health. $\mathrm{He}$ is of the opinion that in view of the serious doubts that exist over the credibility of your entire application, your representations relating to your mental health that you made to Dr. [Name] are not credible. Therefore he concludes that his conclusions in relation to your state of mental health must consequently be flawed, as they are based on those representations. (emphasis Al)

\section{Amnesty International comment}

The Home Office has failed to consider the content of the medical report independently of the asylum claim before evaluating it in context. The reasoning behind this assertion is that because the applicant has 'lied' about his asylum claim, he has 'lied' about his mental health, and an experienced and qualified psychiatrist has proved to be more gullible than the Home Office. It denies the ability of medical practitioners to be alert to malingering, obfuscation and exaggeration. This finding undermines the medical profession and the asylum process.

Amnesty International believes medical evidence should never be dismissed on the presumption that a qualified doctor is simply 'going along with' the account that he or she is given. Where there is doubt over the concluding opinions expressed in a medicolegal report, the Home Office could commission its own independent medical evidence from a clinician of equivalent or higher standing.

\section{The consideration of asylum claims in which torture is alleged: the domino effect}

The inadequacy of initial decision making on cases where torture is alleged can affect applicants throughout the asylum process, creating a 'domino effect'.

As seen earlier in this chapter, where there has been no opportunity to produce medical evidence before an initial decision is made, the Home Office often denies the credibility of the alleged torture on unreasonable grounds, or dismisses the allegation altogether owing to the lack of a medical report. In the majority of cases there appears to be little or no allowance for further medical evidence to be obtained before an initial decision is made - and very little scope for reconsidering a case once a Refusal letter has been issued. ${ }^{62}$

\section{Appeals}

In many cases, the adjudicator at the Immigration Appellate Authority (IAA) will be the first decisionmaker to consider medical evidence in support of the case. Cases received by Amnesty International indicate that medical evidence on asylum cases, where it is available, is usually considered for the first time at the appeal stage in the UK. This is due to two main factors:

1. Often lack of evidence, or 'insufficiency' of evidence, is one reason for the initial refusal and therefore medical reports are obtained by the solicitor for the appeal hearing.

2. There is more time from the submission of the initial SEF application to the appeal hearing in which to obtain medical evidence in support of an asylum claim.

This means that medical evidence, which could 
prove central to a case, is often not an issue in the decision that is being appealed against but is actually being considered, and decided upon, for the first time. Therefore, medical evidence is often considered after a decision that the applicant is not credible.

Asylum applicants can be seriously disadvantaged by having medical reports considered at the appeal stage, rather than the initial decision stage. If medical reports, as often happens, are considered by adjudicators to be of 'poor quality', or 'insufficient' at appeal, rather than prior to the initial decision, there may be no further opportunity to present medical evidence that meets the adjudicator's standards. Currently a further appeal to the Immigration Appeals Tribunal (IAT), can proceed on points of law only. ${ }^{63}$ It is intended that the IAT will disappear altogether in the near future, and will be replaced by a court that is supervised only by itself: the Asylum Immigration Tribunal (AIT). ${ }^{64}$ If this intention is realised, it is probable that asylum applicants will very rarely have the opportunity to advance argument on the basis of further medical documentation in most cases. This makes the first appeal stage crucial to the consideration of the case.

Appeal determinations received by Amnesty International indicate that in many cases, IAA adjudicators and IAT chairpersons accept and continue the line of adversarial credibility denial which has been put into motion by the Home Office. Respondents from the Home Office (Home Office Presenting Officers) are not required to be legally trained. ${ }^{65}$

Home Office Presenting Officers do not always attend the appeals court. According to the 'Best Practice Guide to Asylum and Human Rights Appeals' their failure to attend court 'has increased markedly in recent years'. ${ }^{66}$ However, whether they are in attendance or not, the Home Office will usually rely on the same inadequate reasoning it put forward at the initial stage in the Refusal letter, as well as any other refusal issues not previously mentioned - and the adjudicator may accept that reasoning. ${ }^{67}$ Often, appeal determinations contain assertions about asylum applicants that would be inconceivably hostile in any other area of law where a person claimed that they had suffered injury and abuse.

Immigration Appellate Authority determinations shown to Amnesty International suggest that where medical evidence is submitted for the first time at appeal:

It is often considered only in the context of the 'credibility' of the applicant's account. This can result in qualified medical practitioners who provide reports being accused of simply 'accepting' a non-credible history.
There is evidence that clinical judgements are made by adjudicators who are not medically qualified, for example, on the timings of injuries as a measure of credibility or the likelihood of rape based on 'non-conclusive' medical findings.

Amnesty International believes that the immigration appeal courts should present an opportunity for issues concerning medical treatment to be advanced rather than considered for the first time. The Home Office should adjust its policy to ensure that if medical evidence is required, this is made clear to the applicant from the beginning of their asylum claim. The opportunity to obtain the required medical evidence should be given in cases where torture is alleged, and should be accepted from any qualified practitioner. If medical evidence is at fault in itself, ie because it does not cite the $\mathrm{CV}$ of its author, or it does not deal with the issue in a way that is acceptable to the decision-maker, the applicant should not be penalised and the medical practitioner and/or the applicant should be given the opportunity to respond, or the Home Office should obtain its own medical evidence.

A case that recently came to the attention of Amnesty International, demonstrates the problems that applicants can face at each stage of the asylum process. It concerned a man who had been tortured in Syria by methods well known to Amnesty International. He had been raped in detention by a method known as the 'Black Slave', which involves being blindfolded and forced to sit on a stick. He had also suffered penile rape as well as beating. The methods of torture inflicted were extremely difficult for him to talk about and the full details were disclosed after the initial decision was made. However, allegations of sexual torture were made from the beginning of the claim. In the context of this applicant's particular background, Amnesty International believes that he would face a serious risk of further torture on return to Syria, and possible loss of life.

\section{Syria}

Refusal letter extract, 2001

You claim that you were tortured everyday whilst detained by the Syrian authorities. However, given the serious nature of your claim, you apparently appear to have (sic) no medical treatment following your torture while in detention.

\section{Amnesty International comment}

This is a denial of credibility based on the failure to obtain medical treatment, which is not followed through with any logical argument. If the assertion is that the applicant is lying about being tortured, there can be no link made 
between that and failing to obtain medical treatment on release. In many countries, including Syria, disclosing torture of this kind to a medical practitioner could have grave results for the victim.

However, if lack of medical treatment casts doubt on the allegation of torture, Amnesty International believes that the applicant should have been allowed time to obtain medical evidence relating to his experience before the initial decision was made, or independent medical evidence should have been commissioned by the Home Office.

\section{Syria continued}

First appeal: Immigration Appellate Authority appeal determination, 2001, extract

The contention he makes in [his] statement is of most severe torture, anal rape by two guards following which he was forced to sit with a stick inserted in his anus bound and gagged. He says he has found it difficult to disclose that information. However, it appears to me that anyone seeking to be entitled to refugee status on the basis of their torture would wish to disclose the more severe aspects of it. He makes no mention of it whatsoever except in his SEF interview in which he makes brief reference to being forced to sit on a stick during detention. He goes as far as to seek medical evidence to support his claim. That evidence is in a report of Dr. [name] who examined him at the Sexual Assault Referral Centre in [city]. It appears to me that that medical report provides no helpful evidence whatsoever. Indeed $\operatorname{Dr}$ [name] puts forward the opinion that her 'findings do not provide medical evidence that $\mathrm{Mr}$ [name] was assaulted as he alleges, but nor do they negate that allegation'. - I find the core of the appellant's count of persecution lacks credibility and is a fabrication designed to gain him access to the United Kingdom.

\section{Amnesty International comment}

At the first appeal stage, the denial of credibility of torture is now based on the late disclosure of anal rape. The applicant's account of sexual torture (being forced to sit on a stick) at his asylum interview is dismissed as a 'brief reference' which would indicate that appropriate questions were not asked at that point in his interview. There is no understanding of the significance of penile rape as possibly being more difficult for the applicant to disclose than sexual assault with an object, owing to its cultural implications and stigmatising nature. The distinction between sexual assault and rape in terms of its significance for the definition of 'persecution' is not made clear.

The medical report is undermined because the doctor 'conceded' that her findings are non-conclusive. This is the case in the majority of diagnoses of torture injuries. The fact that the doctor has found nothing to negate the allegation of assault is significant in the circumstances of her particular field of specialism (she is perhaps faced with documenting false allegations of rape from time to time). But this is overlooked, although it is widely recognised that physical evidence of rape and sexual assault are difficult and sometimes impossible to document in most cases.

Determination of Application for Leave to Appeal to the Immigration Appeals Tribunal, extract

It is arguable that the reasons for the adverse credibility finding are flawed in particular that, if true the Claimant would have disclosed those elements of his claim relating to his - anal rape at an earlier stage. All grounds of appeal may be argued.

\section{Amnesty International comment}

Leave to appeal to the Tribunal was granted on all grounds, specifically on the 'flawed' consideration of the allegation of torture. Despite this, the Tribunal went on to uphold the initial appeal decision:

Second appeal: Immigration Appeals Tribunal, extract We consider the adjudicator was fully justified in concluding that since the appellant had felt able to claim that he was tortured, if his account of anal rape was true he would not have failed to disclose the more significant aspects of such torture... Furthermore, not only had he failed to disclose this information to his own representatives and the immigration authorities, he failed to mention it to his own GP, despite several visits over a period of 11 months until November 2001. Given also that he had mentioned having to sit on a stick, he had already seen fit to mention something of considerable personal embarrassment. The appellant's lack of credibility on this aspect of his claim reflected adversely on other aspects of his evidence.

Although both reports find that the medical evidence does not negate the appellant's claims regarding anal rape, at the same time both emphasise that their reports do not provide evidence that the appellant was the subject of rape or physical abuse. Given findings in such agnostic terms, we see nothing wrong in the adjudicator concluding that medical evidence did not particularly assist the appellant.

\section{Amnesty International comment}

The tribunal has continued the failure to take into account the cultural reasons for the applicant's nondisclosure of rape to his GP and the possible reasons why disclosure of sexual assault may be easier for him to disclose than male rape.

With regard to the applicant's medical reports, the tribunal again found them non-conclusive, but did not consider whether 'conclusive' medical evidence would be possible to obtain in such a case. Again, this is a misunderstanding. Amnesty International believes that where medical evidence explicitly allows for the possibility that the applicant's testimony is correct, it 
should be given due weight.

\section{WORTH INVESTIGATING?}

Records of torture in Syria kept by Amnesty International show that not only are the methods described by the applicant in this case entirely consistent with existing knowledge about Syria, but that other 'invisible' methods are used, which decisionmakers should be aware of, and should therefore investigate at the earliest opportunity

Amnesty International knows of prisoners in Syria being anally raped by security officers and being subjected to the 'Abd el-Aswed ('Black Slave') method of torture by which the victim has a stick forced up his anus, and is made to remain in that position. This torture method was very popular in the 1980 s and continues to this day.

Amnesty International has documented at least 38 forms of torture used by Syrian security officers. Whipping is common, as is the practice of making any and all form of daily ritual, such as washing, eating, shaving, showering, as inhumane as possible. 


\section{Conclusion and Recommendations}

\section{Conclusion}

As demonstrated by the extracts from Refusal letters cited in this report, Home Office initial decision making in asylum claims is failing many applicants. This failure is corroborated by the Home Office's own statistics on asylum applications which show how many refusals are overturned on appeal. Getting more decisions right first time will lead to fewer appeals, speedier results and lower costs. This is particularly pertinent at a time when the government proposes to remove second tier appeal rights and abolish the higher courts' powers to scrutinise decisions of the new appellate authority. ${ }^{1}$

\section{Recommendations}

In the light of the analysis and findings in this report, Amnesty International makes the following recommendations:

\section{Front loading}

- Initial decision making on asylum applications should be 'front-loaded', which means that resources should be focused on good quality, defensible decisions early in the decision-making process. 'Front loading' enhances efficiency by ensuring that the initial Home Office decision is based on a full understanding of the applicant's case and is therefore reliable. This is not only fair, it may also avoid wasting public money on financing appeals against flawed initial refusals.

\section{Training}

The overall calibre and training of caseworkers who take initial decisions on asylum applications needs to be reviewed, as is also recommended by the House of Commons Home Affairs Committee on Asylum Applications report published on 26 January 2004.

- All applications for asylum in the UK should be dealt with by a qualified, specially trained body of professionals.

- All caseworkers dealing with asylum applications should receive long-term continuing training, including external training, in refugee and human rights law and country of origin information. They should have specialist knowledge of international standards relating to the protection of refugees and of the political and human rights situation in the applicant's country of origin. External training would assist in breaking down the culture of negative decision-making which gets passed down from the existing system of inhouse training.

\section{Interviews}

- The asylum applicant should be interviewed by the caseworker responsible for the examination and determination of the claim, who should seek to establish the facts of the case to ensure that the information accurately informs the decision.

- The caseworker should be able to elicit full and relevant information and should make use of all relevant background documentation from the widest possible range of impartial and authoritative sources about the political and human rights situation in the applicant's country of origin.

- In cases where torture is alleged, the interviewer should have in-depth knowledge of torture methods practised in the country of origin of the applicant as well as training in interviewing techniques which enable them to interview survivors of torture and trauma.

- Legal representatives and independent interpreters should be present at asylum interviews to take their own hand-written records of the interview to ensure that there is a full, accurate account of everything that is said and note any issues of procedure or miscommunication that arise.

\section{Country information}

- The establishment of an independent documentation centre (IDC) should be considered. An IDC would have significantly improve the efficiency of the asylum determination system. The IDC would provide objective and independent information on the human rights situation in asylum seekers' countries of origin or any country to which they might be sent. It would be available to all those involved in the determination process - Home Office caseworkers, adjudicators, and the legal representatives of asylum seekers. This would result in savings in the cost and time involved in preparing, hearing and deciding cases. The 
number of appeals would be reduced by avoiding erroneous refusals based upon inaccurate country information. In addition, there would be a significant reduction in the time spent on disputes over conflicting assessments of countries of origin at appeal hearings.

\section{Issues of individual credibility}

- Where unreasonable assertions have been made regarding individual credibility unsupported by adequate reasons or the citation of objective sources, the Home Office should substantively reconsider the asylum claim. The quality of Home Office decision making on asylum claims will only improve when a sufficient mechanism for such monitoring is in place.

\section{Allegations of torture}

- Asylum Policy Instructions should have a widely researched section on 'Torture' which covers all the areas relating to torture, is easy to refer to, and does not indicate that the Medical Foundation is the only reliable source of information on torture.

- No asylum seeker who claims torture should be penalised for non-presentation or inadequate presentation of medical evidence:

- The Home Office's concession to delay a decision pending Medical Foundation medical reports should be extended to reports by practitioners outside the Medical Foundation.

- Where medical evidence submitted by torture survivors is considered to be inadequate, the Home Office should permit the applicant and/or practitioner to respond.

If the Home Office wishes to assert a clinical opinion regarding an applicant's asylum claim it should commission its own independent medical evidence. With regard to clinical opinions on medical reports, the Home Office should commission independent medical evidence from a clinician of equivalent or higher standing.

\section{Decision making}

- Decisions on asylum applications should be based solely on the merits of the case.

- Consideration should be given to taking decision making out of the Immigration and Nationality Directorate of the Home Office, where it is permeated by a culture of negative decision making, and establishing an Independent Refugee Board for the UK.

\section{Monitoring}

- Random sampling of decisions is not adequate for assessment and monitoring of cases and the Home Office should commission a continuing independent review of the quality of its decision making and make public its results. In the interim, the assessment by the Treasury Solicitors of Home Office Refusal letters should be based on accurate information to back the assertions made with regard to country of origin information, individual credibility and allegations of torture, citing objective sources of information. 


\section{Endnotes}

\section{Introduction}

1. In its report on the responses to the consultation on the new legislative proposals on asylum reform, dated December 2003, the Home Office states that while the quality of the initial decision is relevant to the outcome of appeals, it is only one of several factors. Others include the time lag between the decision and the appeal, whether information is placed before the adjudicator which was not placed before the Immigration and Nationality Directorate (IND), whether IND was represented at the appeal and the quality of the adjudicator's decision.

2. House of Commons Home Affairs Committee, Asylum Applications, Second Report of Session 2003-04, Vols 1 and 2.

3. Before discretionary leave to remain expires, it is open to the applicant to make an application for further leave to remain.

4. http://www.ind.homeoffice.gov.uk

\section{Terms and information about the UK's asylum processing system}

5. Handbook on Procedures and Criteria for Determining Refugee Status under the 1951 Convention and the 1967 Protocol relating to the Status of Refugees, Office of the United Nations High Commissioner (UNHCR), re-edited January 1992.

6. Letter from Home Office dated 27 February 2003 regarding the ending of Exceptional Leave to Remain policy.

7. However, Humanitarian Protection does not appear to have been added to the Immigration Rules.

http://www.ind.homeoffice.gov.uk/default.asp?Pageld=3185

\section{The obstacle course}

1 Asylum Policy Instructions, Deciding Claims, Immigration and Nationality Directorate, http://www.ind.homeoffice.gov.uk

2 Paragraph 196 of the UNHCR Handbook on Procedures and Criteria for Determining Refugee Status refers to this:

It is a general legal principle that the burden of proof lies on the person submitting a claim. Often, however, an applicant may not be able to support his statement by documentary or other proof.... Thus, while the burden of proof in principle rests on the applicant, the duty to ascertain and evaluate all the relevant facts is shared between the applicant and the examiner...

3 Screening interviews are carried out on all asylum seekers either at the port of entry or at the Home Office, to check on the applicant's travel route to see if the application can be dealt with by the Third Country Unit. It is at this point that the interviewing officer will ascertain whether the asylum seeker falls into a category deemed appropriate for fast tracking and eligibility for assistance from the National Asylum Support Service (NASS).

4 See Chapter 5 of this report, on applicants who allege torture.
5 Section 55 of the Nationality, Immigration and Asylum Act 2002 withholds welfare support from those who do not claim asylum 'as soon as reasonably practicable' after their arrival in the UK. The Home Secretary announced during the second reading of the Asylum and Immigration Bill on 17 December 2003 that 72 hours rather than the current practice would be regarded as the period within which new arrivals in the UK would normally be expected to claim asylum.

6 See Secure Borders, Safe Haven: Integration with Diversity, White Paper published February 2002.

7 See Asylum Legal Aid: The Way Forward, the Legal Services Commission's response to the consultation on proposed changes to publicly funded immigration and asylum work http://www.legalservices.gov.uk/contract/immigration/dca_anno uncement_271103.pdf

8 Understanding the decision-making of asylum seekers, Vaughan Robinson and Jeremy Segrott, 2002.

9 Asylum Policy Instructions on the Medical Foundation, Immigration and Nationality Directorate http://www.ind.homeoffice.gov.uk

10 See Immigration Appellate Authority, Gender Guidelines, 5.32.The asylum applicant should be asked whether she would like a female interpreter.

11 The Legal Services Commission will only pay for attendance at interviews conducted by the Home Office where the client is subject to a Home Office fast-track process; to be interviewed by an Immigration Officer under the Police and Criminal Evidence Act (PACE); where the client is a minor or where the client suffers from 'mental incapacity'.

12 See Recruitment in IND - www.ind.homeoffice.gov.uk. Executive Officers who interview asylum applicants and take decisions on asylum claims need two A-levels and three GCSEs (one of which must be in English Language) or equivalent qualifications.

13 Report on the responses to the consultation on the new legislative proposals on asylum reform in December 2003.

14 Under the Nationality, Immigration and Asylum Act 2002, a list of 'safe'countries was introduced from which claims would be presumed to be 'unfounded', denying applicants an effective right of appeal against refusal.

See House of Commons Home Affairs Committee, Asylum Applications, Second Report of Session 2003-04, Volume 1, Paragraph 132.

15 Home Affairs Committee inquiry into asylum applications, 8 May 2003: response to Q26 by Beverley Hughes MP, Home Office Minister, and Ken Sutton, Deputy Director General of Asylum Support and Casework at the Home Office.

16 Home Office report on the responses to the consultation on the new legislative proposals on asylum reform, December 2003.

17 According to the Home Office, the intention was to have the same person conduct the interview, make the decision and 
present the appeal. Home Office Presenting Officers are HEO grade.

18 An exception to this occurs where an application is made to the administrative court or Court of Appeal.

19 This list comprises Albania, Bangladesh, Bolivia, Brazil, Bulgaria, Cyprus, the Czech Republic, Ecuador, Estonia, Hungary, Jamaica, Latvia, Lithuania, Macedonia, Malta, Moldova, Poland, Romania, Serbia and Montenegro, Slovakia, Slovenia, South Africa, Sri Lanka, and Ukraine.

20 Countries presently appearing on the Fast Track Suitability list include Zimbabwe, Ivory Coast and Afghanistan (except for claims from women).

\section{Getting it wrong}

1 Country Assessments, produced by the Immigration and Nationality Directorate of the Home Office, are available on http://www.ind.homeoffice.gov.uk, under Asylum in the UK/Country information.

2 Home Office Country Assessments: An Analysis, Immigration Advisory Service Research and Information Unit, 2003.

3 Home Office Research Study 271, Country of origin information: a user and content evaluation, Beverley Morgan, Verity Gelsthorpe, Heaven Crawley and Gareth A Jones, Home Office Research, Development and Statistics Directorate, September 2003.

4 See Best Practice Guide to Asylum and Human Rights Appeals, Mark Henderson, Immigration Law Practitioners' Association (ILPA) and Refugee Legal Centre, 2003, p179.

5 See Best Practice Guide to Asylum and Human Rights Appeals, op cit, p179. Also: Home Office Research Study 271, op cit, p17.

6 Home Office Research Study 271, op cit, p69.

7 Advisory Panel on Country Information, Minutes of first meeting, held on 2 September 2003.

8 Letter to Amnesty International from Professor Stephen Castles, Chair of the Advisory Panel on Country Information, 31 October 2003.

9 Home Office Research Study 271, op cit, p40.

10 ibid, p66.

11 Asylum Policy Instructions, RFRL and PF1, Immigration and Nationality Directorate, http://www.ind.homeoffice.gov.uk

12 Ibid.

13 Home Office Research Study 271 op cit, p79.

14 Amnesty International prefers the term 'Internal Protection Alternative' (IPA) because it is more consistent with human rights protection principles. Amnesty International does not oppose forced return to alternative regions of an asylumseeker's home country, if, after a fair and individualised examination, it is clear that the region is legally and safely accessible for the individual, and the proposed region offers durable and effective human rights protection.

15 Asylum Policy Instructions, Additional Considerations - Internal Flight, Immigration and Nationality Directorate, http://www.ind.homeoffice.gov.uk

16 See Asylum Gender Guidelines, Immigration Appellate Authority, Crown Copyright, November 2000, 2B12:

An asylum seeker's gender must be taken into consideration when deciding whether internal relocation is reasonable or unduly harsh. Financial, logistical, social, cultural, legal and other barriers may significantly affect a woman's ability to travel to another area of the country, and to stay there without facing hardship.

17 See note 15 , above.

\section{A negative culture}

1 Handbook on Procedures and Criteria for Determining Refugee Status, op cit, paragraph 202.

2 Home Office Research Study 271, op cit, p66.

3 Asylum Policy Instructions, Further Representations and Fresh Applications, Immigration and Nationality Directorate, http://.ind.homeoffice.gov.uk

4 See Still No Reason At All, Asylum Aid, May 1999, which conducted an in-depth examination of Reasons for Refusal letters following its initial report in 1995, No Reason At All: An asylum system stands or falls by the quality of its decision-making. If Britain is to live up to its claimed tradition of giving shelter to refugees, there has to be a just process for deciding who warrants this country's protection under the 1951 Convention. In 1995, Asylum Aid brought the issue of poor Home Office decision-making to public attention with its report No Reason At All. It highlighted that unfair and arbitrary methods were the norm in deciding on asylum claims, and that many people with valid reasons for seeking the UK's protection were refused asylum on the basis of cursory and careless examination and fundamental misunderstandings of the situations of refugees. Still No Reason At All revisits the issue, surveying decision-making since 1995, and makes similar findings.

Amnesty International has received many asylum cases over years and finds that there has been no improvement in the quality of decision-making since Still No Reason At All was published. See http://www.asylumaid.org.uk

5 For information about consideration of discrepancies in asylum cases see An Overview of Protection Issues in Western Europe: Legislative Trends and Positions Taken by UNHCR, European Series, Vol 1, No 3, Geneva, September 1995; New Issues in Refugee Research: Common burdens and standards: legal elements in assessing claims to refugee status, Working Paper No. 68, Brian Gorlick, UNHCR Evaluation and Policy Analysis Unit, October 2002; Best Practice Guide to Asylum and Human Rights Appeals, op cit. For information about the likelihood of discrepancies arising in the accounts of asylum seekers, see 'Discrepancies in autobiographical memories - implications for the assessment of asylum seekers: repeated interviews study', Jane Herlihy, Peter Scragg and Stuart Turner, British Medical Journal (bmj.com), February 2002; Right First Time? Home Office Asylum Interviews and Reasons for Refusal Letters, EllieSmith, Medical Foundation for the Care of Victims of Torture, February 2004; Errors of recall and credibility: Can omission and discrepancies in successive statements reasonably be said to undermine credibility of testimony? Dr Juliet Cohen, Medico-Legal Journal, 69 (1): 25-34, 2001, available at Medical Foundation website: http://www.torturecare.org.uk

6 Handbook on Procedures and Criteria for Determining Refugee Status, op cit, paragraph 222.

7 Ibid.

8 Asylum Policy Instructions, Immigration and Nationality Directorate, http//ind.homeoffice.gov.uk 
9 Handbook on Procedures and Criteria for Determining Refugee Status, op cit, paragraph 190.

10 See Professor James C Hathaway, The Law of Refugee Status.

11 Asylum Policy Instructions, Deciding Claims, op cit.

12 Asylum Policy Instructions, Miscellaneous Guidance for Caseworkers/Interviews, Immigration and Nationality Directorate, http://ind.homeoffice.gov.uk

13 Best Practice Guide to Asylum and Human Rights Appeals, op cit, p6.

14 The date of the Chinese New Year varies from year to year.

15 See New Issues in Refugee Research, op cit, p13: Inconsistencies, misrepresentations or concealment of certain facts should not lead to a rejection of the asylum application where they are not material to the refugee claim. Contradictions or inconsistencies should relate to the fundamental or critical aspects of the claim to be deemed to undermine the applicant's credibility.

16 Asylum Policy Instructions, RFRL and PF1, op cit.

17 See extracts of Refusal letters in Chapter 3 of this report ('Getting it wrong'), specifically those from Algeria, Iran and Colombia.

18 See http://web.amnesty.org/library/Index/ENGMDE130382003

19 Asylum Policy Instructions, Deciding Claims, op cit.

20 The National Asylum Support Service (NASS) of the Immigration and Nationality Directorate (IND).

21 The Asylum and Immigration (Treatment of Claimants, etc) Bill, House of Commons 27 November 2003, s.15. For the purposes of defining whether a person can be subjected to electronic monitoring as an adult:

In this section 'adult' means an individual who appears to be at least 18 years old in the opinion of a person who - (a) imposes a residence restriction (b) could impose a reporting restriction or (c) grants immigration bail.

An Immigration Officer has all of these powers.

22 Guidelines on Policies and Procedures in dealing with Unaccompanied Children Seeking Asylum, Office of the United Nations High Commissioner for Refugees Geneva, February 1997.

23 S.2 of the Asylum and Immigration (Treatment of Claimants, etc.) Bill, House of Commons 27 November 2003, criminalises the act of entering the UK without a valid passport. S.2(5)(iii) limits a 'reasonable cause' defence for having destroyed documents by discounting typical reasons why an asylum seeker may take such an action.

24 See Handbook on Procedures and Criteria for Determining Refugee Status, op cit, paragraphs 94 \& 95:

A person who was not a refugee when he left his country but who becomes a refugee at a later date, is called a refugee 'sur place'. A person becomes a refugee 'sur place' due to circumstances arising in his country of origin during his absence.

25 New Issues in Refugee Research, op cit.

26 Handbook on Procedures and Criteria for Determining Refugee Status, op cit, paragraph 40.

27 Asylum Policy Instructions, RFRL \& PFI, op cit.

28 Asylum Policy Instructions, Deciding Claims, op cit

29 Justice Maurice Kay, S,D,T v Secretary of State for the Home Department [2003] EWHC 1941 (Admin).

\section{Talking of pain}

1 'Torture' throughout this section refers to the definition given in the United Nations Convention against Torture and Other Cruel, Inhuman or Degrading Treatment, Article 1:

For the purposes of this Convention, the term 'torture' means any act by which severe pain or suffering, whether physical or mental, is intentionally inflicted on a person for such purposes as obtaining from him or a third person information or a confession, punishing him for an act he or a third person has committed or is suspected of having committed, or intimidating or coercing him or a third person, or for any reason based on discrimination of any kind, when such pain or suffering is inflicted by or at the instigation of or with the consent or acquiescence of a public official or other person acting in an official capacity. It does not include pain or suffering arising only from, inherent in or incidental to lawful sanctions.

2 Combating Torture: A manual for action, Amnesty International Publications, 2003, p2.

3 Criminal Justice Act 1988, s.134(1): A public official or person acting in an official capacity, whatever his nationality, commits the offence of torture if in the United Kingdom or elsewhere he intentionally inflicts severe pain or suffering on another in the performance or purported performance of his official duties

4 For further information about international legislation prohibiting torture, Combating Torture: A manual for action, op cit, 2003 and Istanbul Protocol: Manual on the Effective Investigation and Documentation of Torture and Other Cruel, Inhuman or Degrading Treatment or Punishment, United Nations Publications, 9 August 1999, paragraph 1:

The right to be free from torture is firmly established under international law. The Universal Declaration of Human Rights, the International Covenant on Civil and Political Rights and the Convention against Torture and Other Cruel, Inhuman or Degrading Treatment or Punishment all expressly prohibit torture.

5 Medical Foundation for the Care of Victims of Torture, www.torturecare.org.uk

6 For example, see Examining Asylum Seekers: A Health Professional's Guide to Medical and Psychological Evaluations of Torture, Physicians for Human Rights, August 2001;

'Discrepancies in autobiographical memories: Implications for the assessment of asylum seekers; repeated interview study', Jane Herlihy, Peter Scragg, Stuart Turner, British Medical Journal, 2001; Problems in Medical Report Writing for Asylum Seekers, Michael Peel, Ashgate Publishing Limited, 1998.

7 As if the past had not occurred: Late Disclosure: Implications for Clause 82 of the Nationality, Immigration \& Asylum Bill 2002, an unpublished lobbying paper prepared by the Medical Foundation for the Care of Victims of Torture, 2002, p14.

8 'Discretionary Leave' and 'Humanitarian Protection'. For further information, see the Introduction to this report and the Home Office website: http://www.ind.homeoffice.gov.uk

9 According to article $1 \mathrm{~A}(2)$, the term 'refugee' shall apply to any person who:

...Owing to a well-founded fear of being persecuted for reasons of race, religion, nationality, membership of a 
particular social group or political opinion, is outside the country of his nationality and is unable or, owing to such fear, is unwilling to avail himself of the protection of that country...

10 In the case of Sivakumaran (1988 Imm AR147), the House of Lords decided that there has to be demonstrated a reasonable degree of likelihood that an applicant will be persecuted for a Convention reason if returned to his own country. The definition of the standard of proof in asylum cases was developed in the Tribunal case of Kaja $(11038,1995 \mathrm{Imm}$ AR 1) where the Tribunal stressed that a lower standard of proof is required.

11 Incorporated into UK law by the Human Rights Act 1998.

12 Handbook on Procedures and Criteria for Determining Refugee Status, op cit, paragraph 196, states:

While the burden of proof in principle rests on the applicant, the duty to ascertain and evaluate all the relevant facts is shared between the applicant and the examiner. Indeed, in some cases, it may be for the examiner to use all the means at his disposal to produce the necessary evidence in support of the application.

13 Asylum Policy Instructions, RFRL and PF1, op cit.

14 Refers to those received by Amnesty International during 2003.

15 This extract typifies the consideration of Article 3 of the ECHR

in Refusal letters received by Amnesty International.

16 Article 3 of the ECHR provides an absolute prohibition on removal in cases where a person will face torture and/or inhuman or degrading treatment or punishment. Unlike the 1951 UN Refugee Convention, it does not convey 'status' of any kind or make any provision for the enjoyment of rights of a person within the territory of protection.

17 This is found in the Asylum Policy Instructions, Outside organisations/Medical Foundation, Immigration and Nationality Directorate, http://www.ind.homeoffice.gov.uk

18 Asylum Policy Instructions, Outside organisations/Medical Foundation op cit.

19 Right First Time? Home Office Asylum Interviews and Reasons for Refusal Letters, EllieSmith, Medical Foundation for the Care of Victims of Torture, February 2004.

20 See Best Practice Guide to Asylum and Human Rights Appeals, op cit. As if the past had not occurred, op cit. For information on appropriate techniques for interviewing female asylum applicants, see Gender Guidelines for the Determination of Asylum Claims in the UK, Refugee Women's Legal Group, July 1998.

21 Amnesty International's interview with representatives of the Medical Foundation for the Care of Victims of Torture, January 2004.

22 Asylum Policy Instructions, RFRL and PF1, op cit.

23 "Every morning, just like coffee". Torture in Cameroon, Olivia Ball, the Medical Foundation for the Care of Victims of Torture, 26 June 2002.

24 Statutory Instrument no.306: The National Health Service (Charges to Overseas Visitors) Regulations 1989.

25 See Guide to Health Workers Providing Care for Asylum Seekers and Refugees, Dr Angela Burnett, Medical Foundation Series, 2002. For comment and case studies, see: Asylum Health Hurdles, BBC News, 6 May 2001; Asylum Seekers and Health: a BMA \& Medical Foundation for the Care of Victims of Torture dossier, British Medical Association website,

http://www.bma.org.uk p1:

Health care for asylum seekers in Britain is patchy, belated and often inappropriate. The entitlements are there and certainly there are some excellent initiatives. But entitlement is not the same as access in practice...

26 See Rule 35 of Detention Centre Rules 2001.

27 See Protection not Prison: Torture Survivors Detained in the UK, Susi Dell and Mary Salinsky, Medical Foundation, 2001.

28 Ibid.

29 Ibid. Although psycho-therapeutic treatment may be made available to a torture survivor in detention in the UK, the Medical Foundation believes that it should not be carried out in a detention environment and that torture survivors should be released.

30 See Asylum Gender Guidelines, Immigration Appellate Authority, op cit, 5.47:

Special care must be taken in relation to evidence pertaining to sexual violence; care must be taken before drawing any adverse inferences where an appellant, or other witness, has earlier described a rape as an attempted rape or as touching, beating or other ill-treatment or even as pain or illness.

31 Amnesty International interview with the Medical Foundation for the Care of Victims of Torture, January 2004.

32 See Combating Torture: A manual for action, op cit; Medical Foundation for the Care of Victims of Torture, www.torturecare.org.uk

33 For further information, see Istanbul Protocol: Manual on the Effective Investigation and Documentation of Torture, op cit, paragraph 158; Problems in Medical Report Writing for Asylum Seekers, op cit.

34 Guide to Health Workers Providing Care for Asylum Seekers and Refugees, op cit, p15.

35 United Nations Convention against Torture and Other Cruel, Inhuman or Degrading Treatment, 1984.

36 Problems in Medical Report Writing for Asylum Seekers, op cit, p4.

37 Gender Guidelines for the Determination of Asylum Claims in the $U K$, op cit, s.5.38.

38 See Asylum Gender Guidelines, Immigration Appellate Authority, op cit at s.5.47.

39 See Combating Torture: A manual for action, op cit, p13.

40 Advice for Victims of Rape/Male rape, Metropolitan Police, http://www.met.police.uk/sapphire/advice.htm

41 See Gender Guidelines for the Determination of Asylum Claims in the UK, op cit; As if the past had not occurred, op cit.

42 Incorporated into UK law by the Human Rights Act 1998.

43 Asylum Policy Instructions, Assessing the Asylum Claim, Immigration and Nationality Directorate,

http://www.ind.homeoffice.gov.uk. See also, Handbook on Procedures and Criteria for Determining Refugee Status, op cit, paragraph 57.

44 Asylum Policy Instructions, Outside organisations/Medical Foundation, op cit:

If during the course of an interview or in other written representations, an applicant claims to have been tortured, we should ask whether a medical examination has taken place. If so, the applicant should be asked to submit a copy of the report. Where the applicant has raised torture, and the 
caseworker feels it would be useful, we may invite the applicant to submit a medical report. (emphasis Al)

45 Amnesty International interview with the Medical Foundation for the Care of Victims of Torture, January 2004.

46 Amnesty International interview with the Medical Foundation for the Care of Victims of Torture, January 2004.

47 As if the past had not occurred, op cit. Solicitor Katherine Henderson is quoted on p23:

We are moving to an opposite extreme from delay in decision making to the point that we cannot get the kind of specialist reports required in the time-scale set. Under the new legislation, [a fast track applicant] would] be refused before we have had time to get all the evidence and possibly removed from the country.

48 See Asylum Policy Instructions, Outside organisations/Medical Foundation, op cit: Special arrangements have been agreed to allow requests for an extension of a period for post-interview representations for the Medical Foundation to prepare and submit a medical report. Such requests should be carefully considered and only refused in exceptional circumstances.

49 For information about services for torture survivors outside London, contact the Medical Foundation for the Care of Victims of torture at: regional@torturecare.org

50 The Medical Foundation waives its fees in circumstances where a report would not otherwise be produced and where, in its opinion, a report would make a material difference.

51 It is helpful to both applicant, and interviewer to have medical evidence presented at the asylum interview. The interviewer is able to refer to the medical documentation for details and the interviewee may feel more secure about disclosure.

52 For further information, see www.legalservices.gov.uk. The Medical Foundation is very concerned about the curtailing of 'disbursements' (funding) for medical reports on asylum cases. There is concern that Legal Services Commission Officers will not be equipped to evaluate cases in order to determine which ones warrant an extension of disbursements. There is also concern that Medical Foundation reports might be favoured over those of other qualified experts, and that too much weight will be placed on Medical Foundation reports in cases where, for logistical reasons, the Medical Foundation is unable to provide one. Where the Medical Foundation is unable to provide a report, the Legal Services Commission may wrongly infer a judgement about the 'credibility' of applicants who allege torture.

53 From April 2004, each asylum applicant will be provided with a 'Unique Client Number' which could make it extremely difficult for them to obtain advice from an alternative solicitor in cases where their current one is failing to provide an adequate service. This will disadvantage all asylum applicants who have suffered from poor legal advice and representation. However the impact on survivors of torture is potentially the most serious.

54 Lives Under Threat: A study of Sikhs coming to the UK from the Punjab, second edition, Medical Foundation for the Care of Victims of Torture, July 1999, p52.

55 Asylum Policy Instructions, Outside organisations/Medical Foundation, op cit.
57 Asylum Policy Instructions, The Medical Foundation, Immigration and Nationality Directorate, http://www.ind.homeoffice.gov.uk

58 Medical Foundation website, www.torturecare.org.uk; Right First Time? op cit; As if the past had not occurred, op cit.

59 Dr Paul Williams, MBBS MRCGP DCH DRCOG DFFP DTM\&H, General Practitioner and founder of 'Arrival', an NHS practice for asylum seekers in Stockton-on-Tees.

60 Gender Guidelines for the Determination of Asylum Claims in the $U K$, op cit, 5.46: 'It should be noted that there is frequently no physical evidence in cases involving rape or sexual violence'; Problems in Medical Report Writing for Asylum Seekers, op cit, p3: ... in sexual abuse cases in particular, there may well be no objective physical evidence of damage. Many of the women have had children before they are raped, and it is difficult to attribute damage to the genitalia, however violent the assault.

Istanbul Protocol: Manual on the Effective Investigation and Documentation of Torture, op cit, paragraph 219: 'It is rare that a victim of rape during torture is released while it is still possible to identify acute signs of the assault'; The health of survivors of torture and organised violence, Angela Burnett \& Micheal Peel, bmj.com, http://bmjjournals.com; Guide to Health Workers Providing Care for Asylum Seekers and Refugees, op cit.

61 Istanbul Protocol: Manual on the Effective Investigation and Documentation of Torture, op cit, paragraph 160.

62 The Home Office arrangement to receive medical evidence after the interview and prior to the initial decision being made applies only to applicants who can provide written confirmation at the interview that a Medical Foundation report will be produced. See also, Asylum Policy Instructions, Further Representations and Fresh Applications, Immigration and Nationality Directorate, http://www.ind.homeoffice.gov.uk

63 See Appeals to the Immigration Appeal Tribunal (IAT), Court Service, http://www.iaa.gov.uk, s.10.

64 Asylum and Immigration (Treatment of Claimants, etc) Bill, House of Commons, 27 November 2003.

65 See Recruitment in IND/Executive Roles, Immigration and Nationality Directorate, http://www.ind.homeoffice.gov.uk

66 Best Practice Guide to Asylum and Human Rights Appeals, op cit.

67 For further information about appeals and Home Office Presenting Officers' reliance on Refusal letters, see Best Practice Guide to Asylum and Human Rights Appeals, op cit.

\section{Failing asylum seekers}

1 The only possible challenge to the decision of the appellate authority would be for the appellate authority itself to conduct an internal review. 